\title{
Kinematic evolution of the Araçuaí-West Congo orogen in Brazil and Africa: Nutcracker tectonics during the Neoproterozoic assembly of Gondwana
}

\author{
Fernando F. Alkmim ${ }^{\mathrm{a}, *}$, Stephen Marshak ${ }^{\mathrm{b}}$, Antônio Carlos Pedrosa-Soares ${ }^{\mathrm{c}}$, \\ Guilherme Gravina Peres ${ }^{a}$, Simone Cerqueira Pereira Cruz ${ }^{\mathrm{a}}$, Alan Whittington ${ }^{\mathrm{d}}$ \\ a Departamento de Geologia, Escola de Minas, Universidade Federal de Ouro Preto 35.400.000 Ouro Preto, Minas Gerais, Brazil \\ ${ }^{\mathrm{b}}$ Department of Geology, University of Illinois, Urbana, IL, USA \\ c Instituto de Geociências, CPMTC, Universidade Federal de Minas Gerais, 31.270.901, Belo Horizonte, Minas Gerais, Brazil \\ ${ }^{\mathrm{d}}$ Department of Geological Sciences, University of Missouri, Columbia, MO, USA
}

Received 9 December 2005; received in revised form 10 June 2006; accepted 22 June 2006

\begin{abstract}
The Neoproterozoic Araçuaí-West Congo (A-WC) orogen is one of many Brasiliano/Pan-African orogens that developed during the assembly of West Gondwana. This orogen was split apart in Mesozoic time, due to opening of the South Atlantic—the Araçuaí orogen now underlies eastern Brazil, whereas the West Congo belt fringes central Africa's Atlantic coast. Significantly, at the time it formed, the A-WC orogen was bounded on the west, north, and east by the São Francisco-Congo craton, a crustal block that had the shape of a lopsided, upside-down ' $U$ '. Thus, the orogen was "partially confined" during tectonism, in that it occupied an enclave surrounded on three sides by cratonic crust. Formation of the A-WC orogen resulted in kinematically complex deformation, substantial crustal shortening, and production of a large volume of magma. How such features could develop in this particular setting has long been a mystery. Our field studies in the Araçuaí orogen, together with published data on the West Congo belt, characterize the kinematic picture of the A-WC orogen, and lead to a tectonic model that addresses its evolution. In our model, the A-WC orogen formed in response to closure of the Macaúbas basin. This basin was underlain by oceanic crust in the south, but tapered northward into a continental rift which terminated against the cratonic bridge linking the eastern and western arms of the São Francisco-Congo craton. Closure occurred when the western arm (now the São Francisco craton) rotated counterclockwise towards the eastern arm (now the Congo craton). This closure may have been driven by collision of the Paranapanema, Amazonian, and Kalahari cratons against the external margins of the São Francisco-Congo craton, rather than by slab-pull associated with subduction of the Macaúbas basin's floor. Thus, the process of forming the A-WC orogen resembled the process of crushing of a nut between two arms of a nutcracker. Such "nutcracker tectonics" led to a series of kinematically distinct deformation stages. Initially, internal portions of the orogen flowed northwards. Then, substantial crustal thickening occurred in the orogen's interior, and the deformation front migrated outwards, producing thrust belts that overlapped the internal margins of the craton. With continued closure, space in the enclave became restricted and the orogen's interior underwent lateral escape to the south. Late-stage extensional collapse triggered both production of late- to post-collisional granites and exhumation of high-grade rocks from mid-crustal levels.
\end{abstract}

(C) 2006 Elsevier B.V. All rights reserved.

Keywords: Araçuaí orogen; West Congo belt; Neoproterozoic; Brasiliano/Pan-African orogenies; Confined orogen; West Gondwana; Collisional tectonics

\footnotetext{
* Corresponding author. Tel.: +55 31 35591600; fax: +55 3135591606.

E-mail addresses: ffalkmim@gmail.com, alkmim@degeo.ufop.br (F.F. Alkmim).
} 


\section{Introduction}

Reconstructions of West Gondwana (De Wit et al., 1988; Porada, 1989; Trompette, 1994; Daziel, 1997) suggest that, prior to the opening of the South Atlantic in the Cretaceous, the São Francisco craton of Brazil was connected to the Congo craton of Africa, creating a single continental block that had the shape of a lopsided upsidedown ' $U$ ' (Fig. 1). The west arm and the top of the ' $U$ ' comprise the present-day São Francisco craton, and the bulbous eastern arm of the ' $U$ ' comprises the presentday Congo craton. Porada (1989) referred to the top of the ' $U$ ' as the "São Francisco-Congo cratonic bridge". The youngest deformation and metamorphism within the bridge occurred during the 2.1-1.9 Ga TransamazonianEburnean event (Ledru et al., 1994; Toteu et al., 1994; Trompette, 1994; Feybesse et al., 1998; Silva et al., 2002; Barbosa and Sabaté, 2004; Lerouge et al., 2006), indicating that the bridge remained intact between Paleoproterozoic time and the Cretaceous, when the Atlantic rift cut through the bridge.
Prior to Cretaceous rifting, the inner margin of the São Francisco-Congo craton surrounded an enclave containing an orogen that formed during the Neoproterozoic-early Paleozoic Brasiliano/Pan-African orogenies. Cretaceous rifting separated this orogen into the Araçuaí orogen of present-day Brazil, and the West Congo belt of present-day west-central Africa. Henceforth, we refer to the combined Brasiliano/Pan-African deformation province that existed before Cretaceous rifting as the Araçuaí-West Congo (A-WC) orogen (Fig. 1). The tongue-like shape of the A-WC orogen (surrounded on the west, north, and east by cratonic crust) has long puzzled geologists. This shape implies either that the AWC orogen, at the time of formation, terminated along strike against cratonic crust at its north end, or that structural trends in the orogen curved through $180^{\circ}$, following the internal edge of the São Francisco-Congo craton. In either case, the amount of deformation, crustal thickening, and magmatic activity that occurs in the orogen is difficult to reconcile with the partially confined setting in which the orogen formed.

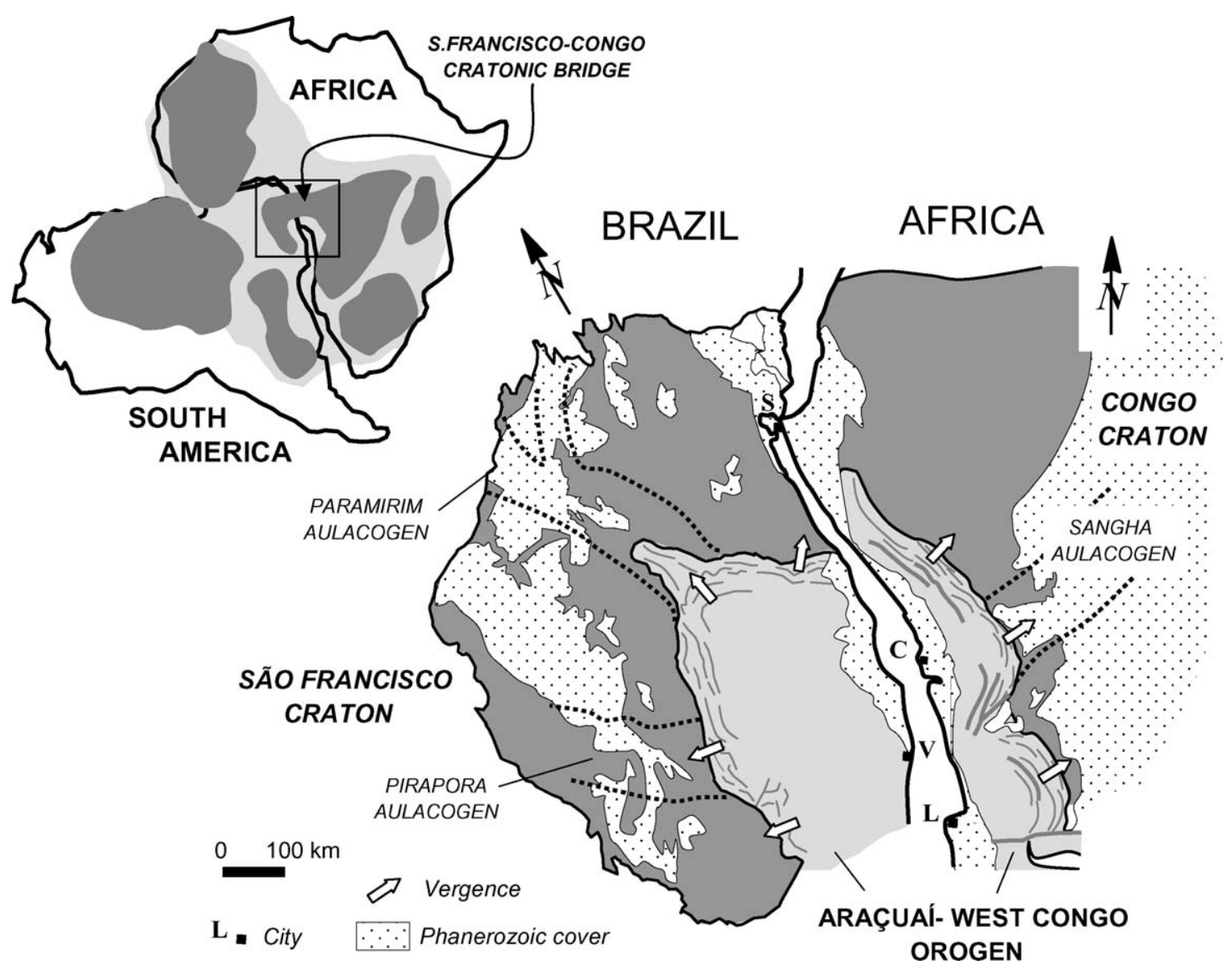

Fig. 1. The Araçuaí-West Congo orogen and the adjacent São Francisco-Congo craton in the context of West Gondwana. South America-Africa fit after De Wit et al. (1988). V = Vitória, $S=$ Salvador; $L=$ Luanda; $C=$ Cabinda. 
In order to provide kinematic constraints addressing the question of how the A-WC orogen formed and evolved, we undertook structural analysis of the Araçuaí orogen in eastern Brazil. This work provides a basis to interpret both the unusual shape of the orogen, as well as a variety of puzzling metamorphic relationships and igneous events. The purpose of this paper is first to present a synthesis of observations on both the stratigraphy and structure of the A-WC orogen (using both our own observations and published data), and then to describe the kinematic evolution of the orogen. We present a new model suggesting that the A-WC orogen formed in response to "nutcracker tectonics."By using this term, we mean that the orogen formed when the western arm of the São Francisco-Congo craton rotated counterclockwise toward the eastern arm, compressing the intervening Macaúbas basin like a nut squashed by a nutcracker. Our results have implications for the general issue of how partially confined orogens evolve.

\section{Regional context of the Araçuaí-West Congo orogen}

West Gondwana (combined Africa and South America) assembled in the Neoproterozoic and early Paleozoic (640-520 Ma) when several small continental blocks were stitched together by a network of orogens to form a complex crustal mosaic (Trompette, 1994, 1997; Brito Neves et al., 1999; Almeida et al., 2000). The collisions and basin closures that produced this mosaic are the Brasiliano orogenies of Brazil, and the Pan-African orogenies of Africa. Notably, each of the major continental blocks that became incorporated in West Gondwana was cored by a craton. The São Francisco-Congo, Rio de la Plata, Amazonian, West Africa, Tanzania, and Kalahari cratons (Fig. 1) of West Gondwana correspond to relatively strong lithospheric pieces formed during the Archean and Paleoproterozoic.

The present-day São Francisco craton, which in mapview resembles the profile of a horse's head, underlies part of the highlands of southeastern Brazil (Fig. 1). Paleo- and Mesoproterozoic platform deposits cover much of the craton's interior, but erosion has exposed the basement of Archean and Paleoproterozoic rocks both at the craton's southern end and in its northeastern lobe. Present-day cratonic crust of the conjugate margin in Africa comprises a single large block, the Congo craton. The Congo craton has an Archean core with Paleo- and Mesoproterozoic overprints along part of its margins (Trompette, 1994). Several lines of evidence robustly support the concept of the São FranciscoCongo "cratonic bridge", established by the end of the Transamazonian-Eburnian event. This link survived until South Atlantic rifting in the Cretaceous (Porada, 1989; Ledru et al., 1994; Toteu et al., 1994; Feybesse et al., 1998; Barbosa and Sabaté, 2004). Table 1 summarizes this evidence.

During the Precambrian, two rifting events affected the interior of the composite São Francisco-Congo. The first began at ca. $1.75 \mathrm{Ga}$, and produced the Espinhaço rift (Brito Neves et al., 1996), now incorporated in the A-WC orogen, as well as the Paramirim and Pirapora aulacogens (Fig. 1). The second rifting probably began around $900 \mathrm{Ma}$ (Pedrosa-Soares et al., 2001; Tack et al., 2001), and led to the formation of the broader Macaúbas basin, now incorporated in the A-WC orogen, well as the Sangha aulacogen (Alvarez and Maurin, 1991; Maurin, 1993; Trompette, 1994; Alvarez, 1995) (Fig. 1). The Macaúbas basin, overlapped the relicts of the Espinhaço rift system, and broadened southwards into a narrow ocean. But Macaúbas rifting did not cut through the

Table 1

Evidence indicating that the São Francisco and Congo Cratons were linked by a cratonic bridge, prior to the Brasiliano/Pan-African Orogeny

Lack of Brasiliano/Pan-African deformation along the coast of Bahia (Brazil) and Gabon (Africa)

No dated Brasiliano/Pan-African orogenic features have been found along coastal segments of Brazil, Gabon and Cameroon, where the bridge between the São Francisco and Congo cratons was broken. The most recent tectonothermal events recorded in this crust are Paleoproterozoic (Barbosa and Sabaté, 2004; Ledru et al., 1994; Toteu et al., 1994; Feybesse et al., 1998; Lerouge et al., 2006). Furthermore, an undeformed basic dike swarm, dated at ca. $1.0 \mathrm{Ga}$., crops out along the coast of both Brazil and Congo in crust that lay in the São Francisco-Congo bridge (D'Agrella Filho et al., 1990, 2004; Corrêa-Gomes and Oliveira, 2000)

Paleopole positions

Paleomagnetic poles for the São Francisco and Congo cratons roughly coincide for pre-Brasiliano time, indicating that the two cratons were already close together at the time of the Brasiliano/Pan-African orogeny (D'Agrella Filho et al., 1990, 2004; Renne et al., 1990)

Width of the Atlantic continental margins where the margins cut across the bridge

The present continental margins of South America and Africa on conjugate sides of the Atlantic are much narrower where the margins cut across the São Francisco-Congo bridge than where they are bordered by Brasiliano/Pan-African orogens to the north and south (Matos, 1999). The relation suggests that the bridge, at the time of Mesozoic rifting, consisted of strong cratonic crust, not weak orogenic crust, for strong crust breaks without significant initial stretching-a break in strong crust does not produce a wide passive-margin basin 
bridge between the northern São Francisco and Congo cratons.

\section{Lithotectonic assemblages of the A-WC orogen}

\subsection{Overview}

The Araçuaí orogen encompasses the entire region between the São Francisco craton and the eastern Brazilian continental margin, north of latitude $21^{\circ} \mathrm{S}$ (Fig. 2). Our specification of $21^{\circ} \mathrm{S}$ for the southern limit is somewhat arbitrary. At this latitude, the structural grain of the orogen bends from a NNE trend to a northeast trend, and the belt merges with the Ribeira belt, a deformation domain which extends south of $21^{\circ} \mathrm{S}$ for another $800 \mathrm{~km}$ along the southeastern coast of Brazil (Pedrosa-Soares and Wiedemann-Leonardos, 2000; Heilbron et al., 2000; Heilbron and Machado, 2003). We use the term "West Congo belt"for the $1400 \mathrm{~km}$ long and up to $300 \mathrm{~km}$ wide African remnant of the A-WC orogen, because the region contains only a single fold-thrust belt, the eastverging West Congo fold-thrust belt (Fig. 2; Tack et al., 2001). This belt straddles the borders of Gabon, Congo, and Angola, and includes thrust slices of Archean and Paleoproterozoic basement as well as of a thick pile of Neoproterozoic metavolcanic and metasedimentary units (Boudzoumou and Trompette, 1988; Maurin, 1993; Tack et al., 2001). The combined A-WC orogen contains several domains, characterized by their component stratigraphy, structural features, and metamorphic grade. Below, we outline lithotectonic components of the orogen.

\subsection{Lithotectonic assemblages of the Araçuai orogen}

\subsubsection{Pre-1.8 Ga basement}

Following the criteria adopted by Almeida et al. (1981), we consider basement of the Araçuaí orogen to include all units older than $1.8 \mathrm{Ga}$. Accordingly, the basement consists of Archean and Paleoproterozoic metamorphic complexes, granitoids, and supracrustal units. These rocks occur in the northern and southwestern portions of the orogen, as well as in thrust slices and anticlinal cores that have been incorporated into external fold-thrust belts (Fig. 2).

\subsubsection{Paleo/Mesoproterozoic rift assemblage}

The region that now comprises the Araçuaí orogen underwent a major episode of rifting (the Espinhaço phase) at around $1.75 \mathrm{Ga}$ (Brito Neves et al., 1996). This episode produced a basin filled with bimodal volcanics, quartz sandstone, conglomerate, pelite, and subordinate

\section{ARAÇUAÍ OROGEN}
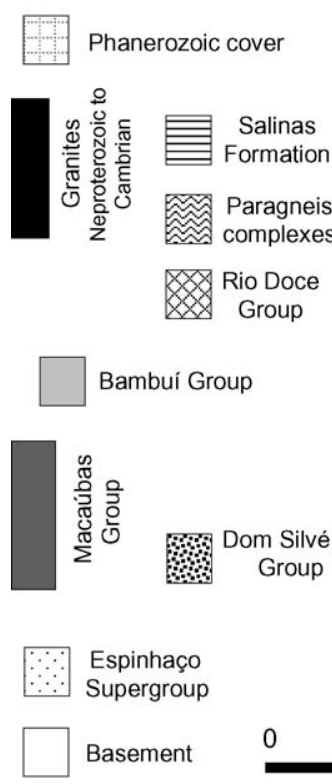
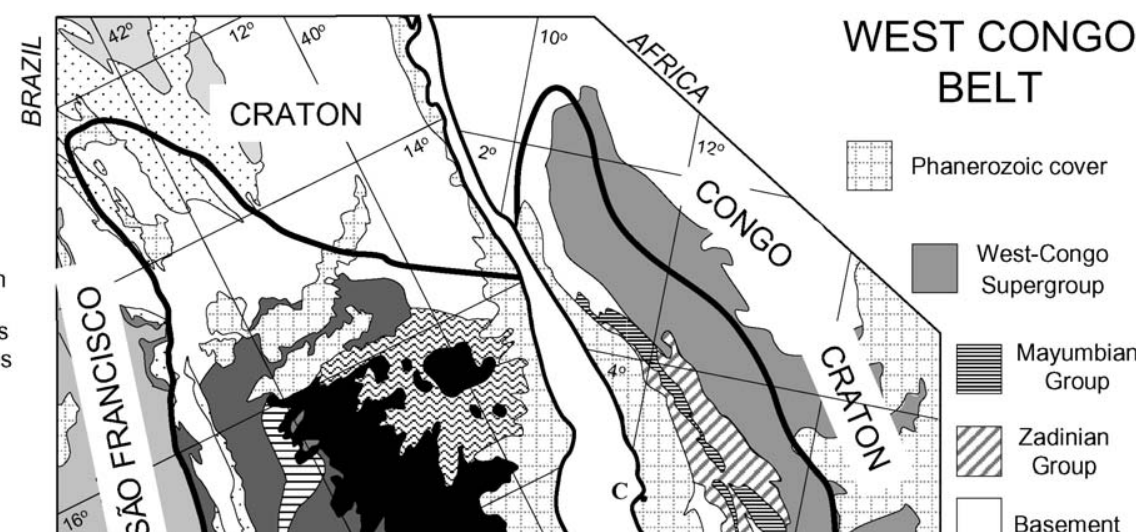
BELT Phanerozoic cover

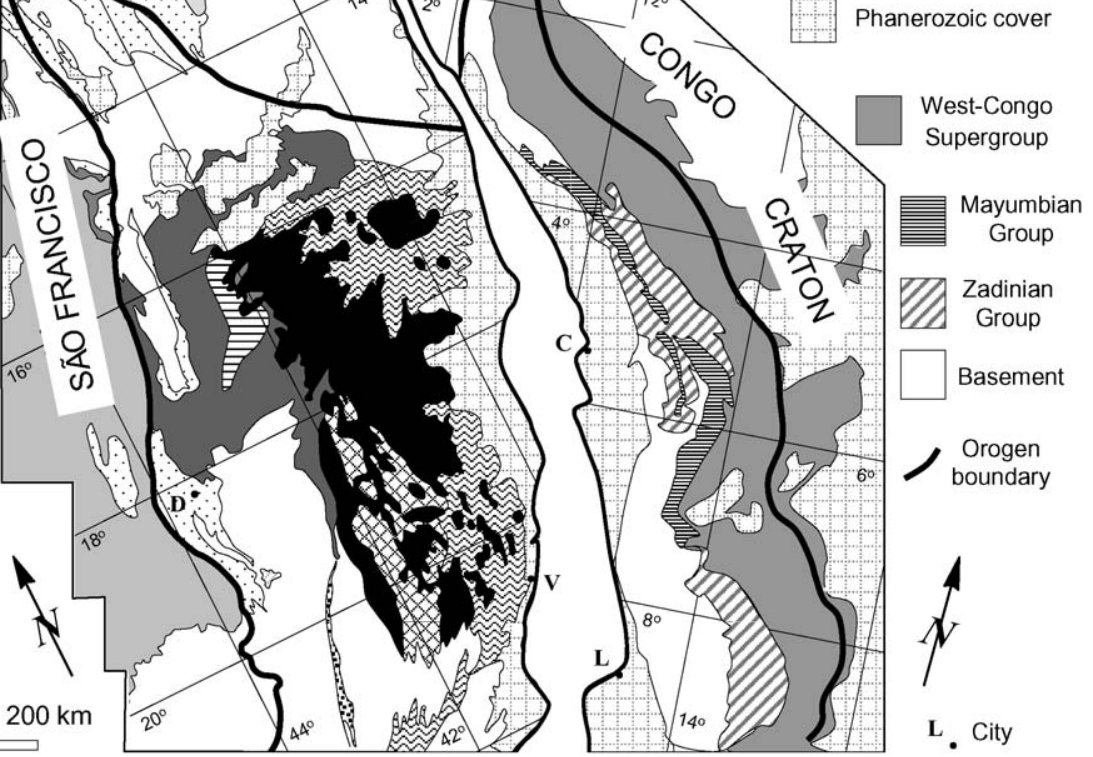

Fig. 2. Distribution of the principal lithostratigraphic units of the Araçuaí-West Congo orogen, based on Pedrosa-Soares et al. (2001) and Tack et al. (2001). Cities: $\mathrm{D}=$ Diamantina, $V=$ Vitória, $C=$ Cabinda, $L=$ Luanda. 
carbonate which, taken together, comprise the approximately $6 \mathrm{~km}$ thick Espinhaço Supergroup (Figs. 2 and 3; Dussin and Dussin, 1995; Uhlein et al., 1998; MartinsNeto, 2000). Strata of the Espinhaço Supergroup now crop out in the external fold-thrust belt on the western margin of the Araçuaí orogen, and in the Paramirim Aulacogen.

\subsubsection{Neoproterozoic rift/ocean basin assemblage}

A second episode of rifting (the Macaúbas phase) occurred in the region now occupied by the Araçuaí orogen, between 1000 and $850 \mathrm{Ma}$ (Pedrosa-Soares et al., 1992; Uhlein et al., 1999; Martins-Neto and Hercos, 2000; Pedrosa-Soares et al., 2000). South of latitude $18^{\circ} \mathrm{S}$, the rift evolved into a narrow ocean basin (PedrosaSoares et al., 1992, 2001). Sedimentary fill of this Neoproterozoic basin comprises the Macaúbas Group (Figs. 2 and 3).

Proximal deposits of the Macaúbas Group crop out in the western (external) part of the Araçuaí orogen.
They consist of tillites, diamictites, sandstones, pelites, and subordinate basic volcanics, metamorphosed up to greenschist facies. These deposits probably record an $850 \mathrm{Ma}$ old glacial event, although their age is not well constrained. Detrital zircons extracted from proximal tillites yield a maximal age of $920 \mathrm{Ma}$ for this unit (Pedrosa-Soares et al., 2000). To the east and south, these strata grade into thick sequences of distal pelites containing intercalations of sandy turbidites (Uhlein et al., 1999; Martins-Neto and Hercos, 2000; Martins-Neto et al., 2001). Distal deposits have been metamorphosed to amphibolite facies, and comprise the Ribeirão da Folha Formation (Fig. 3; Lima et al., 2002). The Ribeirão da Folha Formation also includes an ophiolitic assemblage, composed of metamorphosed basalt, chert, banded-iron formation, gabbro, plagiogranite, and ultramafics. Mafic rocks of the assemblage yield a $\mathrm{Sm}-\mathrm{Nd}$ isochron age of $816 \pm 72 \mathrm{Ma}$ (with $\varepsilon_{\mathrm{Nd}}=+3.8$ ), interpreted as the time of magmatic crystallization (Pedrosa-Soares et al., 1998).

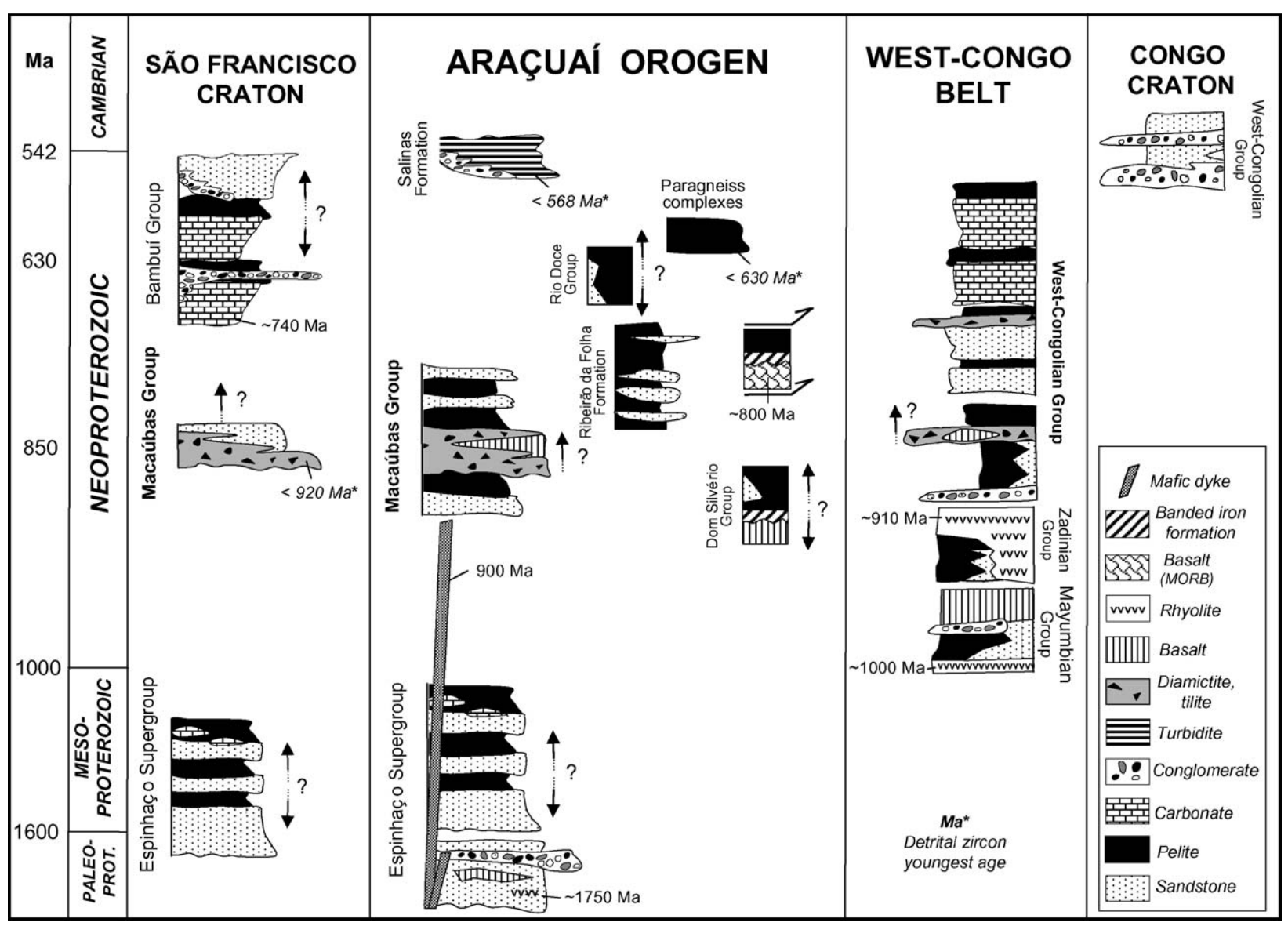

Fig. 3. Stratigraphic columns for the Araçuaí orogen, West Congo belt, and adjacent cratons. See text for explanation and references. 


\subsubsection{Neoproterozoic platformal and foreland deposits}

Platformal and foreland-basin deposits cover a substantial part of the São Francisco craton (Figs. 2 and 3; Martins-Neto et al., 2001; Alkmim et al., 2001). This fill comprises the Bambuí Group, a succession of marine carbonate and pelitic rocks. Basal carbonates of the Bambuí Group have been dated at $740 \pm 20 \mathrm{Ma}$ (Babinski and Kaufman, 2003), and have the isotopic signature of a post-glacial cap carbonate deposited during a high sea-level stand (Kaufmann et al., 2001; Misi et al., 2005). Pelites were shed diachronously from orogens surrounding the craton.

\subsubsection{Neoproterozoic and Early Cambrian granites}

Late Neoproterozoic and early cambrian granites crop out along a $150 \mathrm{~km}$ wide $\times 700 \mathrm{~km}$ long, north-south-trending zone in the interior of the Araçuaí orogen (Fig. 2; Noce et al., 2000; Pedrosa-Soares et al., 2001; Wiedemann et al., 2002; Martins et al., 2004). This zone contains products of five distinct phases of granite generation, referred to as the G1 (oldest) to G5 (youngest) suites (Pedrosa-Soares and Wiedemann-Leonardos, 2000). The ages and tectonic significance of these suites have been constrained by isotopic data, as synthesized by Heilbron et al. (2004). The G1 suite (625-585 Ma), composed of foliated tonalite and granodiorite with minor diorite and mafic enclaves, is the product of subduction-related arc activity in a continental margin setting. The G2 suite (585-560 Ma) consists of S-type granites intruded during the collisional phase. The G3 suite (535-510 Ma) is late- to post-collisional and consists of peraluminous leucogranites. The G4 and G5 suites (520-490 Ma) consist, respectively, of post-tectonic peraluminous S-type granites and high-K calc-alkaline, I-type plutons.

\subsubsection{Paragneiss complexes}

Two paragneiss complexes, the Jequitinhonha and Paraíba do Sul, lie in the eastern and northeastern Araçuaí orogen (Fig. 2). These complexes contain gneiss with variable amounts of peraluminous silicates, as well as subordinate graphite gneiss, quartzite, marble and calc-silicate rock. U-Pb SHRIMP ages of detrital zircons indicate that protoliths of these paragneisses were deposited between 630 and $585 \mathrm{Ma}$ (Noce et al., 2004). Considering their location, these complexes may have been derived from either passive-margin strata of the Macaúbas basin, or the fill of a backarc basin (Pedrosa-Soares and Wiedemann-Leonardos, 2000).

\subsubsection{Other units of the Araçuai orogen}

The Salinas Formation, a thick package of turbidites (greywacke, pelite, and conglomerate) metamorphosed to greenschist grade, crops out in homoclinally dipping panels in the northern portion of the Araçuaí orogen (north of $18^{\circ} \mathrm{S}$; Fig. 2). This unit was deposited between 570 and $500 \mathrm{Ma}$ (Fig. 3; Lima et al., 2002). Because of its location and relatively young age, the Salinas Formation may represent the fill of an intramontane basin formed during a late stage in the history of the Araçuaí orogen.

Two units of uncertain age occur in the internal portion of the orogen, the Dom Silvério and the Rio Doce groups (Fig. 2). The Dom Silvério Group consists of pelitic schist, quartzite, manganese-rich rock, amphibolite, ultramafic rock, and banded iron formation, and thus may include ocean floor and deep-ocean strata. The Rio Doce Group is made up essentially of pelitic schists.

\subsection{Lithostratigraphy of West Congo belt}

The basement in the West Congo belt is exposed in thrust slices and in the undeformed foreland (Fig. 2). Basement of the thrust slices consist of amphibolitegrade gneiss, amphibolite, migmatite, and quartzite, which comprise the $2.1 \mathrm{Ga}$ Kimezian Supergroup (Tack et al., 2001). Basement of the foreland domain consists of Archean gneiss and granitoids (Figs. 2 and 3).

A $10 \mathrm{~km}$ thick supracrustal package, known as the West Congo Supergroup, overlies the basement (Fig. 3). From base to top, this unit includes: the Zadinian Group (1.0-0.92 Ga rift-related clastics, rhyolites, and basalts; Cahen et al., 1984; Tack et al., 2001); the Mayumbian Group (0.92-0.91 Ga acid volcanics intruded by microgranites; Tack et al., 2001); and the West Congolian Group (a passive-margin sequence of clastics and carbonates, overlain by foreland-basin red beds). The West Congolian Group is separated from the underlying units by an unconformity, and includes two diamictite beds, probably recording global glacial events (Cahen et al., 1984; Alvarez and Maurin, 1991; Trompette, 1994; Alvarez, 1995; Tack et al., 2001).

The bimodal meta-volcanic/meta-sedimentary sequence of the Zadinian and Mayumbian groups represents the igneous component of a rift assemblage associated with opening of what, in Brazil, became the Macaúbas basin. The West Congolian Group correlates with the Macaúbas and Bambuí Groups of the Araçuaí orogen and São Francisco craton, respectively (Pedrosa-Soares et al., 1992). No ophiolites or orogenic granites have been identified in the West Congo belt (cf. Trompette, 1994; Tack et al., 2001). 


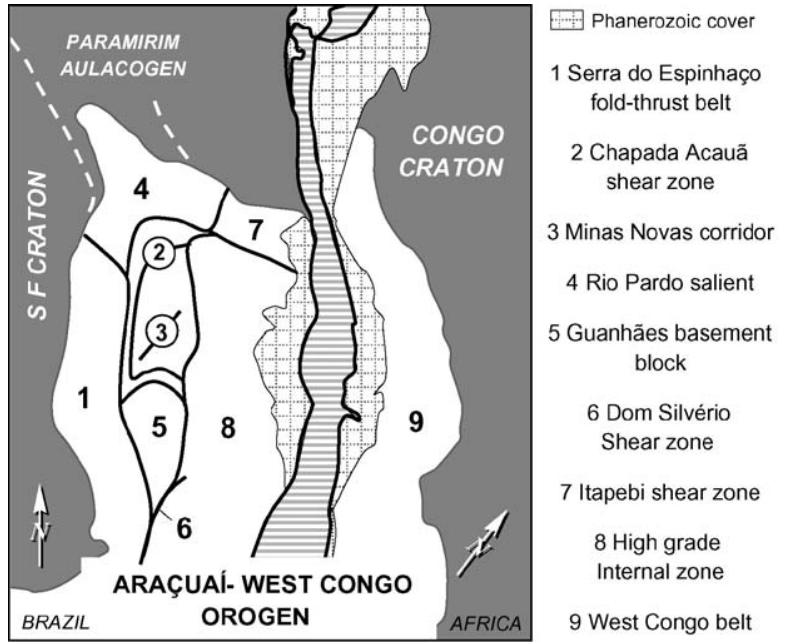

Fig. 4. Structural domains of the A-WC orogen.

\section{Kinematic anatomy of the A-WC orogen}

The A-WC orogen consists of several distinct structural domains (Fig. 4), which differ from each other in terms of style, orientation, deformation history, and shear sense. Below, we provide a structural description of these domains, synthesized from numerous individual studies both by members of our research group and by other authors. Our goal is to provide an image of movements that took place in the orogen during the Brasiliano/PanAfrican orogenic period.

\subsection{Serra do Espinhaço fold-thrust belt}

The Serra do Espinhaço fold-thrust belt is a $700 \mathrm{~km}$ long, NS-trending and west-verging system of faults and folds that fringes the eastern edge of the São Francisco craton. It incorporates Archean basement and strata of the Espinhaço Supergroup and the Macaúbas Group (Fig. 5; Dussin and Dussin, 1995; Uhlein et al., 1998). Thick Espinhaço Supergroup quartzite sequences acted as struts, and buckled into west-verging inclined folds with wavelengths of up to $3 \mathrm{~km}$. These structures contain a spaced to phyllitic cleavage $\left(\mathrm{S}_{1}\right)$, associated with a strong east-west-trending stretching lineation (Uhlein et al., 1986, 1998).

The trace of a major emergent thrust delineates the western edge of the belt. To the west of this thrust, a blind detachment propagated westward beneath deformed Bambui Group platform cover (Marshak and Alkmim, 1989). At its northern end (north of $16^{\circ} \mathrm{N}$ ), the western thrusts of the Serra do Espinhaço fold-thrust belt curve northwest and merge with faults defining the western margin of the Paramirim aulacogen (Fig. 5). At its south end, the fold-thrust belt incorporates Paleoproterozoic and Archean supracrustal rocks of the Quadrilátero Ferrífero mining district (Chemale et al., 1994; Alkmim and Marshak, 1998).

\subsection{Chapada Acauã shear zone}

A $50 \mathrm{~km}$ wide $\times 150 \mathrm{~km}$ long plateau, known as the Chapada Acauã, lies on the east side of the Serra do Espinhaço, north of $18^{\circ} \mathrm{S}$ (Fig. 5). This plateau is underlain by pelites and diamictites of the Macaúbas Group, metamorphosed to greenschist and lower-amphibolite facies. These rocks comprise the hanging wall of a regional east-dipping shear zone, the Chapada Acauã Shear Zone (CASZ; Marshak et al., 2006). At its southern end, the CASZ curves eastward, around the northern border of the Guanhães basement block, and at its northern end, the CASZ curves east and merges with the Itapebi shear zone (Fig. 5).

Based on the geometry of folds, veins, and cleavages that occur in the CASZ, Marshak et al. (2006) proposed that the zone accommodated a phase of top-down-to-theeast (i.e., normal-sense) displacement. The structures associated with this normal-sense phase overprint the west-verging (reverse-sense) structures that formed during development of the Serra do Espinhaço fold-thrust belt. Notably, low-grade strata of Salinas Formation, the youngest sedimentary unit in the Araçuaí orogen, occur in the hanging-wall block of the CASZ.

\subsection{Minas Novas corridor}

The Minas Novas corridor is $30 \mathrm{~km}$ wide and $150 \mathrm{~km}$ long dextral strike-slip shear zone that cuts Macaúbas Group metapelites. The dominant foliation within the corridor is a steep to vertical northeast-striking schistosity. Along the northwestern half of the corridor, foliation dips preferentially to southeast, whereas along the southeastern half, preferentially to northwest. On foliation planes, stretching lineations display variable rakes, averaging around $30^{\circ}$ down to northeast. Tight to isoclinal folds, whose axes are subparallel to the stretching lineations, crop out in central portion of the corridor.

\subsection{Rio Pardo salient}

At a latitude of $16^{\circ} \mathrm{S}$, the internal trendlines of the Serra do Espinhaço fold-thrust belt trace out a regional-scale convex-to-the-foreland curve called the Rio Pardo salient (Fig. 6; Cruz and Alkmim, 2006). A ridge underlain by Macaúbas Group quartzites topographically delineates the salient (Pedrosa-Soares et al., 

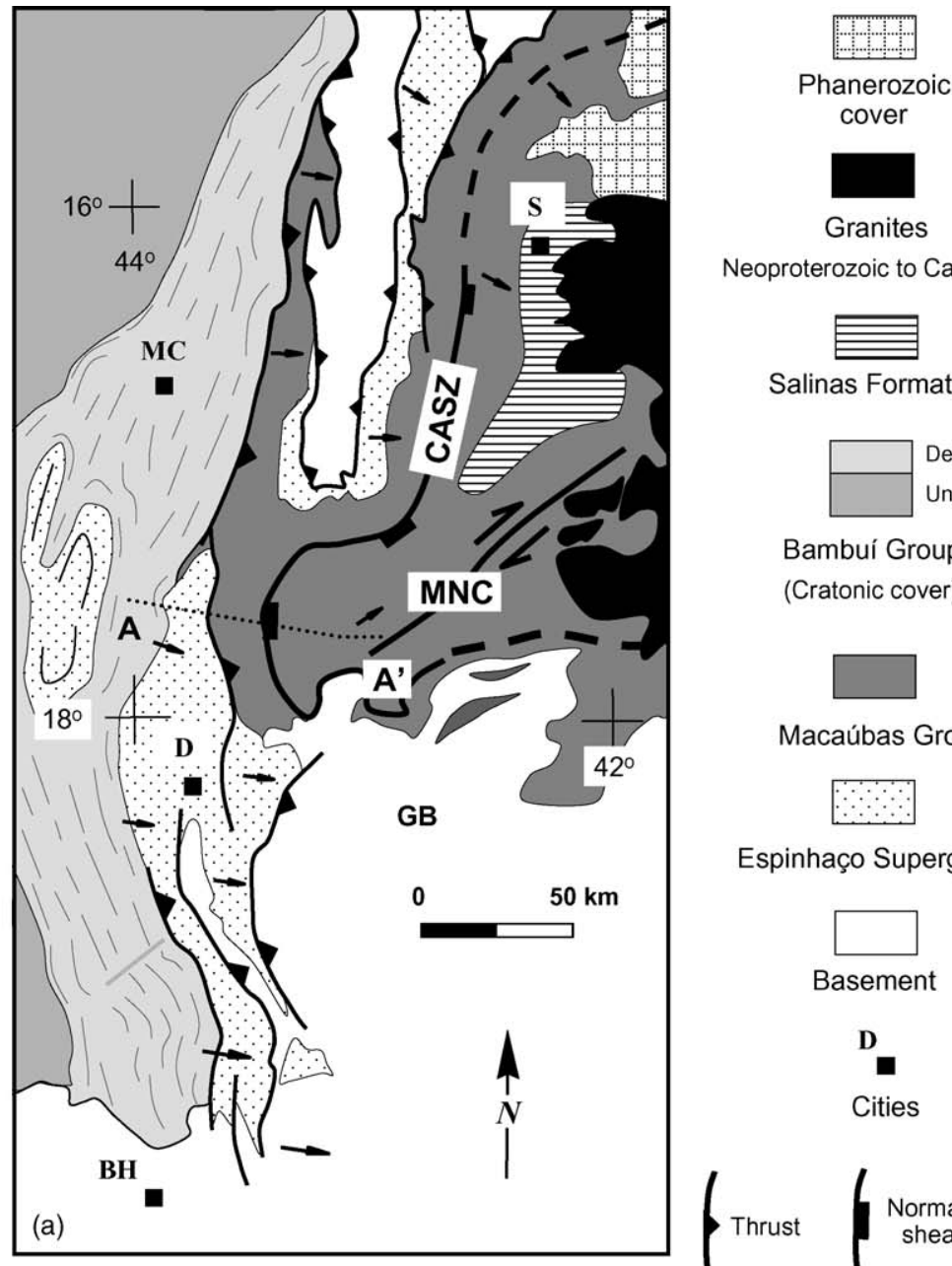

Neoproterozoic to Cambrian

Salinas Formation

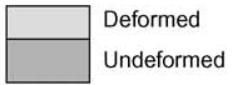

Bambuí Group

(Cratonic cover)

Macaúbas Group

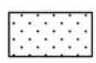

Espinhaço Supergroup
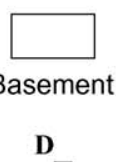

Cities

$\oint$ Thrust $\left\{\begin{array}{c}\text { Normal sense } \\ \text { shear zone }\end{array}\right.$

$\longrightarrow$ Stretching lineation

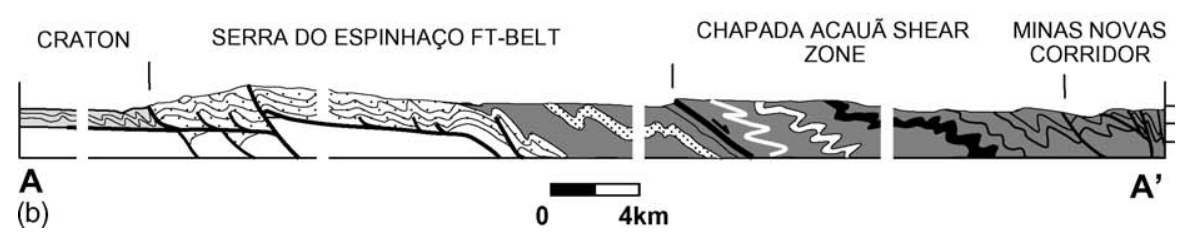

Fig. 5. (a) Schematic structural map of Serra do Espinhaço fold-thrust belt, Chapada Acauã shear zone and Minas Novas corridor. Tectonic features: $\mathrm{GB}=$ Guanhães basement block; CASZ = Chapada Acauã shear zone, MNC = Minas Novas corridor; Cities: $\mathrm{S}=\mathrm{Salinas,} \mathrm{MC}=\mathrm{Montes} \mathrm{Claros}$, D = Diamantina, BH: Belo Horizonte; (b) Simplified cross-section of the central Espinhaço fold-thrust belt and adjacent features. Based on Uhlein et al. (1986, 1998), Pedrosa-Soares et al. (2001) and Marshak et al. (2006).

2001). In the inner arc of the salient, a thick package of Macaúbas Group metaturbidites, with intercalations of metadiamictites, overlies the quartzite.

The basement-cover contact along the outer arc of the salient is marked by a $200 \mathrm{~m}$-thick mylonitic shear zone, which dips $10-25^{\circ}$ toward the inner arc of the curve. Kinematic indicators (e.g., porphyroclast tails, C-S fabrics) indicate thrust-sense motion on the detachment (Cruz and Alkmim, 2006). Metasediments above the detachment are affected by two sets of structures. The older set includes ENE-trending, NNW-verging folds $\left(F_{1}\right)$, associated with an $S_{1}$ penetrative schistosity, and ENE-striking thrusts. The second (younger) assemblage includes NNW-trending folds $\left(\mathrm{F}_{2}\right)$, as well 


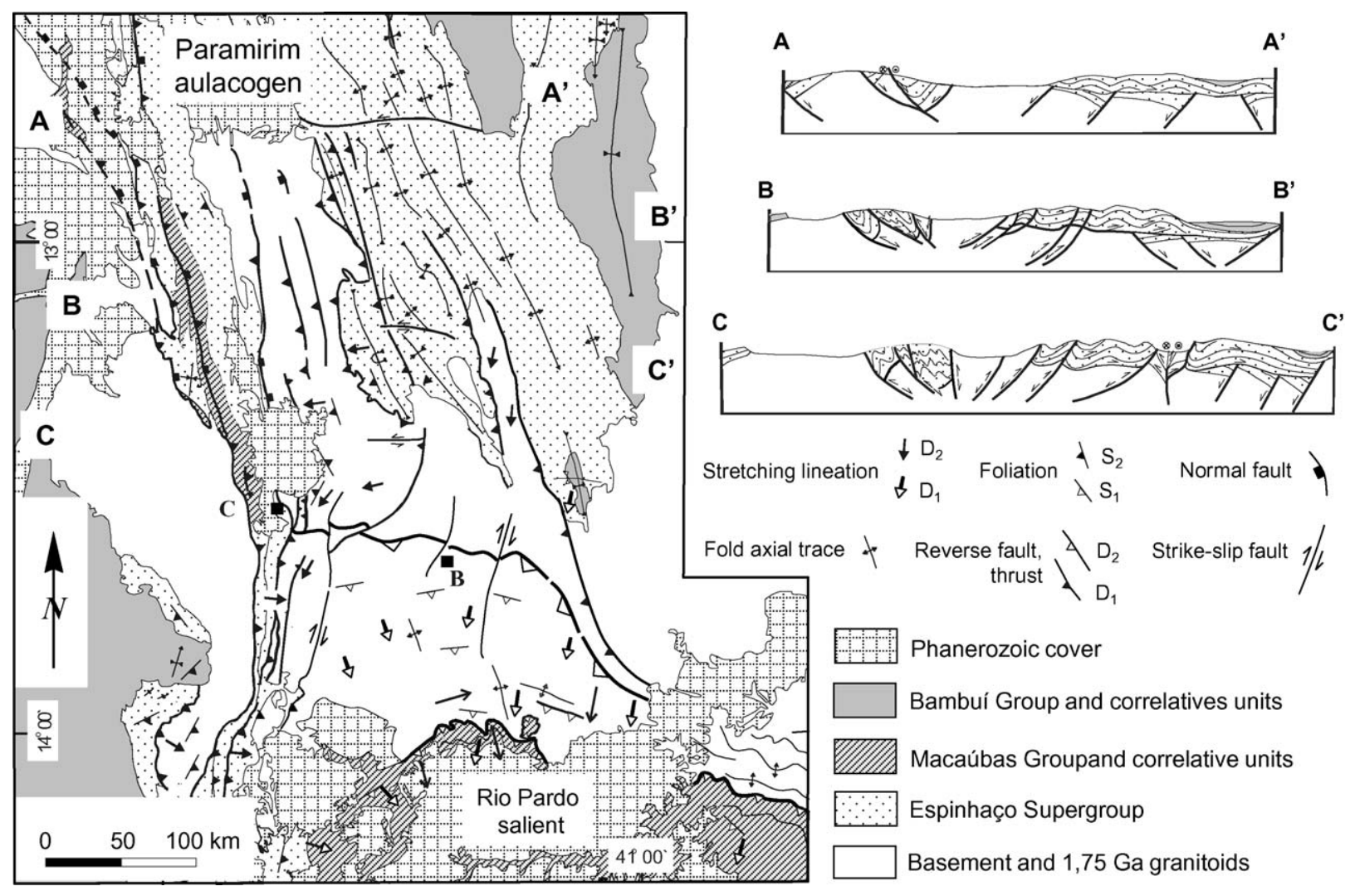

Fig. 6. Structural map and cross-sections of the southern half of the Paramirim aulacogen and the Rio Pardo Salient. Based on Cruz and Alkmim (2006) and Danderfer and Dardenne (2002).

as NNW-trending strike-slip and oblique-slip shear zones. Interference between the two-fold generations produced local dome-and-basin interference patterns. Formation of NNW-verging structures $\left(\mathrm{F}_{1}\right.$ and $\left.\mathrm{S}_{1}\right)$ took place during amphibolite-facies metamorphism, whereas $F_{2}$ folds formed under greenschist-facies conditions.

\subsection{Paramirim aulacogen}

The NNW-trending Paramirim aulacogen marks the boundary between the northeast lobe and the southern lobe of the São Francisco craton (Fig. 6). As noted earlier, it initiated during the Espinhaço rifting event, and was reactivated during the Macaúbas rifting event (Schobbenhaus, 1996; Danderfer and Dardenne, 2002). The Paramirim aulacogen underwent partial inversion during the Brasiliano orogeny (Danderfer and Dardenne, 2002; Cruz and Alkmim, 2006). In the southern twothirds of the aulacogen, this inversion reactivated preexisting normal faults and transfer faults to produced NNW-trending basement-involved thrusts faults linked by strike-slip shear zones. The degree of inversion decreases progressively northwards, until at a latitude of $13^{\circ} 30^{\prime} \mathrm{S}$, where faults along the western margin of the basin retain their original normal-sense of displacement (Fig. 6; Danderfer and Dardenne, 2002). North-verging thrust faults and folds associated with the development of the Rio Pardo salient propagated into the aulacogen, along its axis, at its southern end. The curving thrusts and folds of the salient have been overprinted by the NNW-trending faults and folds formed during inversion, so the inversion event post-dated the development of the Rio Pardo salient (Cruz and Alkmim, 2006).

\subsection{Guanhães basement block}

The Guanhães block is a $250 \mathrm{~km}$ long and $140 \mathrm{~km}$ wide exposure of Archean basement and Paleoproterozoic meta-sedimentary units, located to the southeast of the Serra do Espinhaço fold-thrust belt (Fig. 7). The block likely originated as part of the São Francisco craton. Several plutons of $1.75 \mathrm{Ga}$ anorogenic granites (the Borrachudos Suite) intruded the block (Chemale et al., 1998; Dussin, 2000; Silva et al., 2005). 
Shear zones delineate the margins of the Guanhães block. The western margin is a foreland-verging thrust (Figs. 7 and 8). Top-to-the-west movement on this thrust placed Guanhães block basement over strata of the Espinhaço Supergroup (north of the town of Itabira) and over supracrustal units of the Quadrilátero Ferrífero (south of Itabira). The southeastern margin of the Guanhães block is the Dom Silvério shear zone (see next section), which juxtaposes Rio Doce Group metapelite (on the east) against basement (on the west). The northern margin of the Guanhães block is a shallowly dipping shear zone (the southern end of the CASZ) that juxtaposes Macaúbas Group strata (above) against the basement (below). At this locality, this shear zone records two distinct motions: the first phase was reverse-sinistral, and the second phase was normal-dextral (Fig. 7; Peres et al., 2004).

Three regional-scale shear zones (the Pedra Branca, Sabinópolis and Virgolândia shear zones) bound a northtrending "central belt" in the interior of the Guanhães block. These shear zones initiated as thrusts, probably during development of the Serra do Espinhaço fold-thrust belt, but underwent inversion and accom- modated with normal-sense to normal-dextral motions subsequently (Fig. 7; Peres et al., 2004). This later phase of deformation was associated with upperamphibolite facies metamorphism and generation of granitic melts within the central belt. $\mathrm{Ar}-\mathrm{Ar}$ dating in biotite and phlogopite extracted from the Pedra Branca shear zone yield an age of $509 \pm 2 \mathrm{Ma}$ (Ribeiro-Althoff et al., 1997). Thus, the normalsense to normal-dextral movement phase took place at the end of the Brasiliano orogeny (Peres et al., 2004).

\subsection{Dom Silvério shear zone and adjacent structures}

The $100 \mathrm{~km}$ long, $4 \mathrm{~km}$ wide Dom Silvério shear zone (Fig. 8) is a NNE-trending, steeply dipping belt of mylonitic rock. Motion along this shear zone was dominantly sinistral, as indicated by a variety of shear-sense indicators (Peres et al., 2004).

At its northern end, the Dom Silvério shear zone terminates against the dextral strike-slip Abre Campo shear zone (see next section; Fig. 8). The crustal sliver

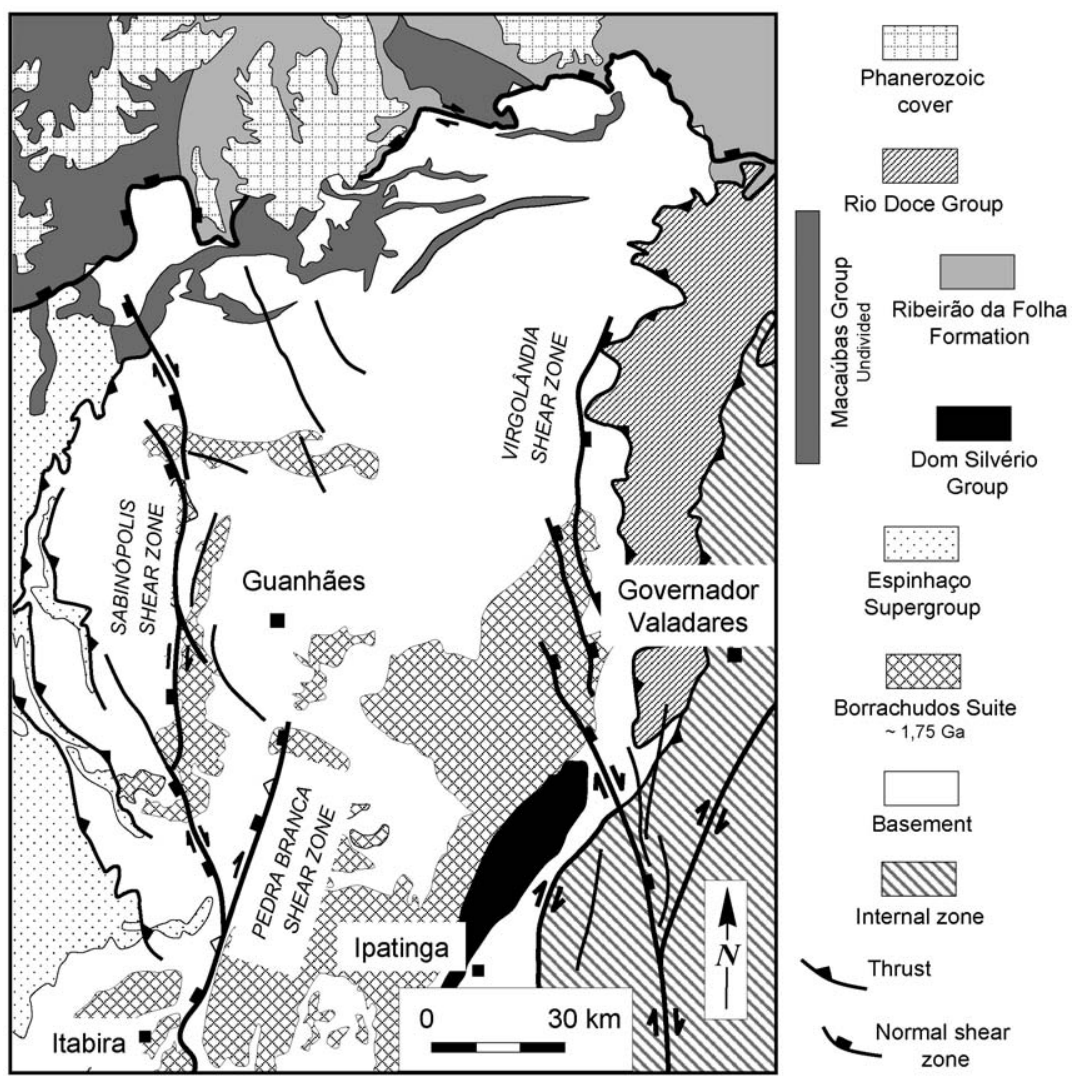

Fig. 7. Simplified structural map of the Guanhães basement block. 
between the Abre Campo and Dom Silvério shear zones is a distinctive domain in the Araçuaí orogen. Here, both Archean basement gneiss and Dom Silvério Group metasediments record two phases of deformation. Structures of the first phase $\left(\mathrm{D}_{1}\right)$ formed during overall top- to-the-north displacement along a now subhorizontal gneissic foliation. $\mathrm{D}_{2}$ structures, in contrast, consist of west-verging folds and related thrust-sense shear zones. The most prominent $\mathrm{D}_{2}$ shear zone is the Ponte Nova thrust, which dips gently to the east, and roots in the
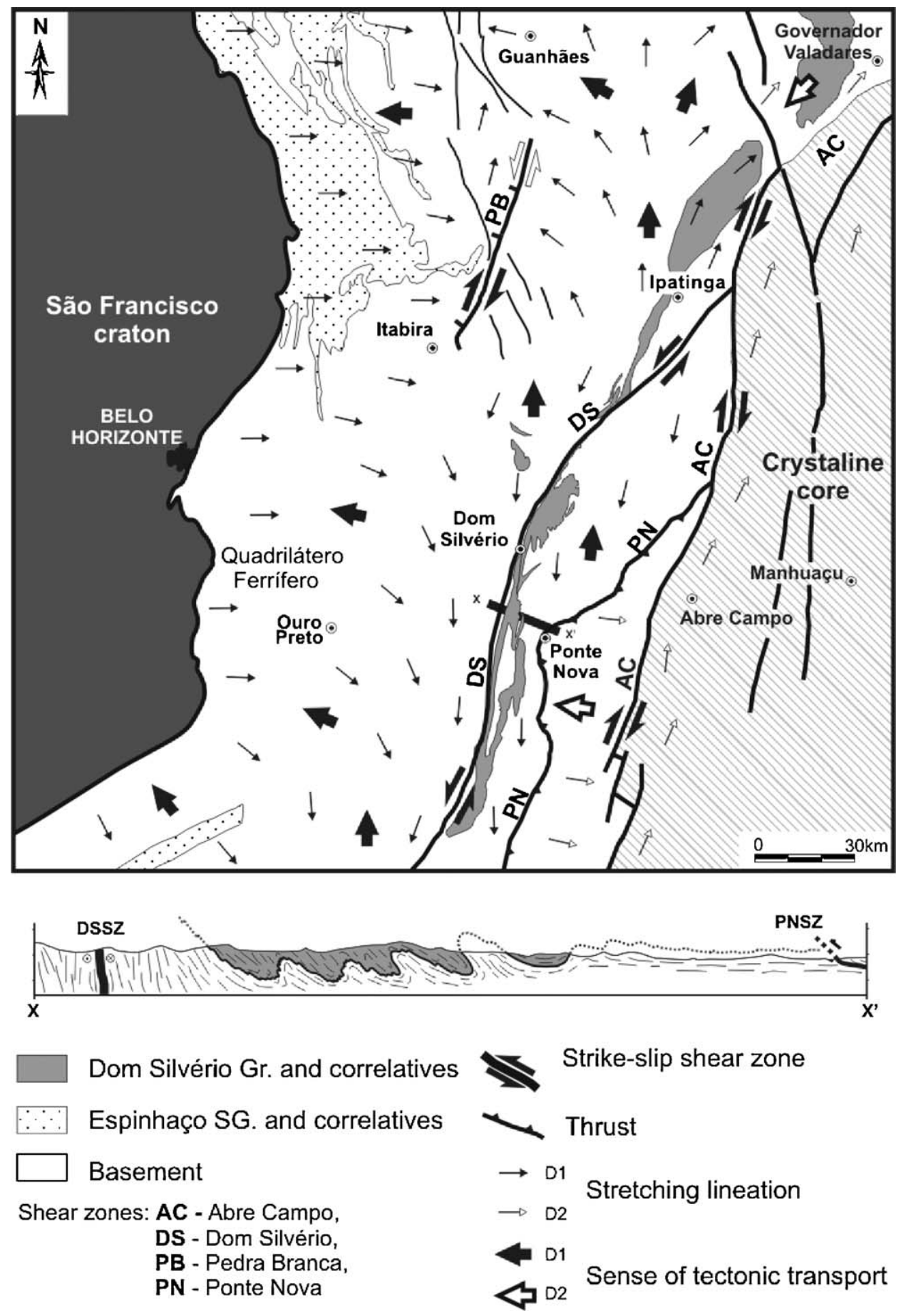

Fig. 8. Structural map of the Dom Silvério shear zone and adjacent structures. Modified from Peres et al. (2004). 
Abre Campo shear zone. Rock in the hanging wall of the Ponte Nova thrust contains a pervasive foliation and an east-plunging lineation. $\mathrm{Sm}-\mathrm{Nd}$ isochrons indicates that amphibolite facies metamorphism associated with $\mathrm{D}_{1}$ took place between 580 and $560 \mathrm{Ma}$ (Brueckner et al., 2000). Metamorphic ages obtained by Fischel et al. (1998) and Silva et al. (2002) fall in the same interval.

\subsection{Itapebi shear zone}

The NW-trending Itapebi shear zone is the main and central structure within an overall dextral transpressional zone that delineates the northern edge of the Araçuaí orogen (Fig. 9). It cuts Archean basement, the 880 Ma Salto da Divisa anorogenic granite (Silva et al., 2005), and the Jequitinhonha Complex. Individual faults in the shear zone anastomose and change dip direction along strike. The sense of slip on the thrust component of this transpressional system is predominantly top-to-the northeast (i.e., towards the northeastern lobe of the São Francisco craton), although local SW-directed motion took place on subsidiary shear zones located to the south of the Itapebi shear zone (Gonçalves and Melo, 2004). Slip lineations and $\mathrm{C}-\mathrm{S}$ fabric suggests that dextral shear on the Itapebi shear zone system was later reactivated with normal-sinistral sense of movement.

\subsection{Structures of the Araçuaí orogen's high-grade internal zone}

The high-grade (crystalline) internal zone of the Araçuaí orogen includes Neoproterozoic-Cambrian granite suites and paragneiss complexes (the Jequitinhonha complex north of $17^{\circ} 30^{\prime} \mathrm{S}$; the Paraíba do Sul complex south of $18^{\circ} 30^{\prime} \mathrm{S}$ ). From a structural standpoint, the internal zone of the Araçuaí orogen consists of two distinct sub-domains. The northern sub-domain (located between $16^{\circ} \mathrm{S}$ and $18^{\circ} 30^{\prime} \mathrm{S}$ ) contains west- and east-verging thrust-sense shear zones, whereas the southern subdomain (south of $18^{\circ} 30^{\prime} \mathrm{S}$ ) contains a system of dextral-transpressional shear zones (Figs. 9 and 10).
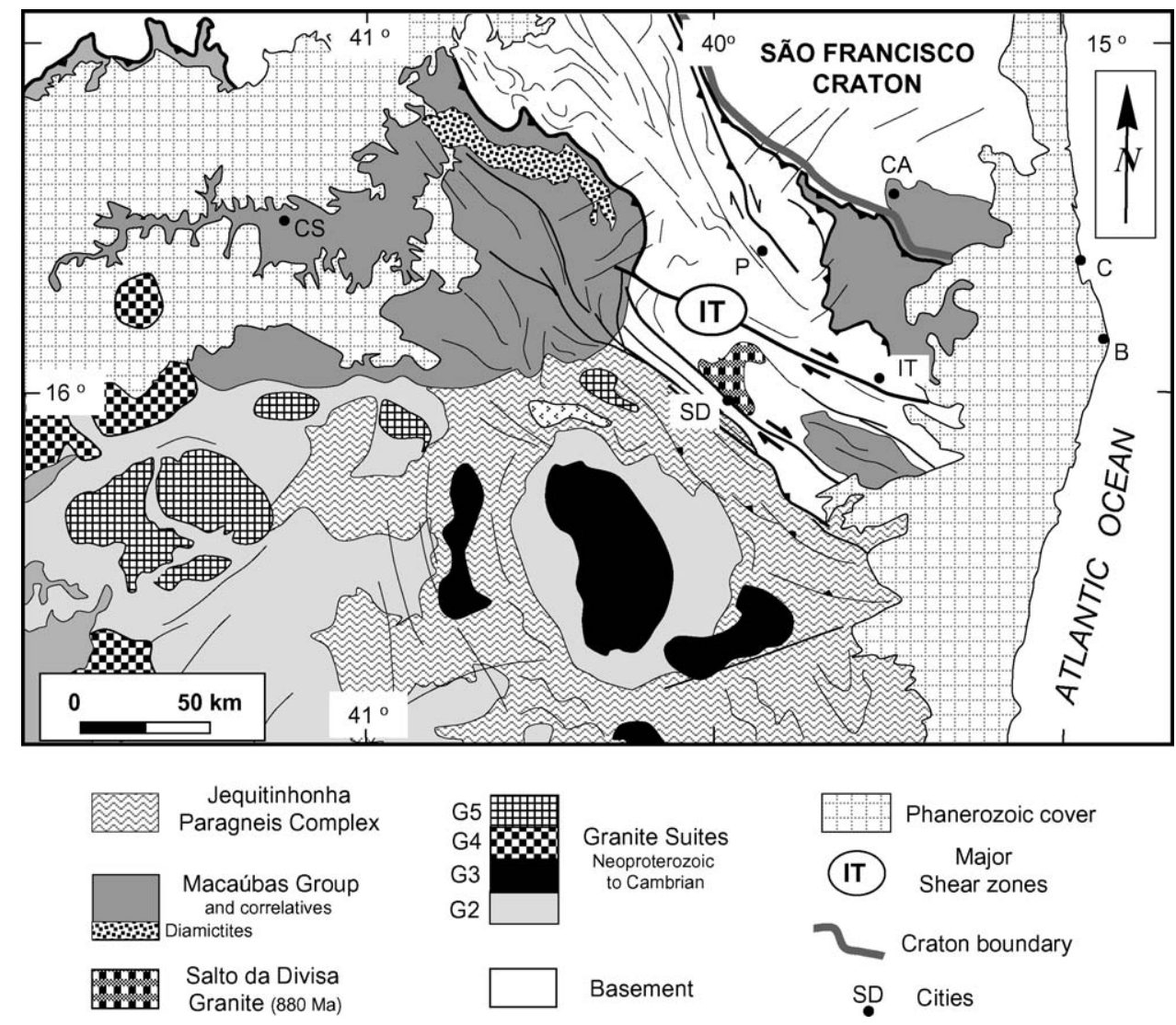

Fig. 9. Simplified structural map of the northeastern portion of the Araçuaí orogen, emphasizing the Itapebi shear zone system. Compiled from Pedrosa-Soares et al. (2001), Gonçalves and Melo (2004). Cities: B = Belmont, C = Caravelas; CA = Camaçã, CS =Cândido Sales, IT = Itapebi, $\mathrm{P}=$ Potiraguá, $\mathrm{SD}=$ Salto da Divisa. 


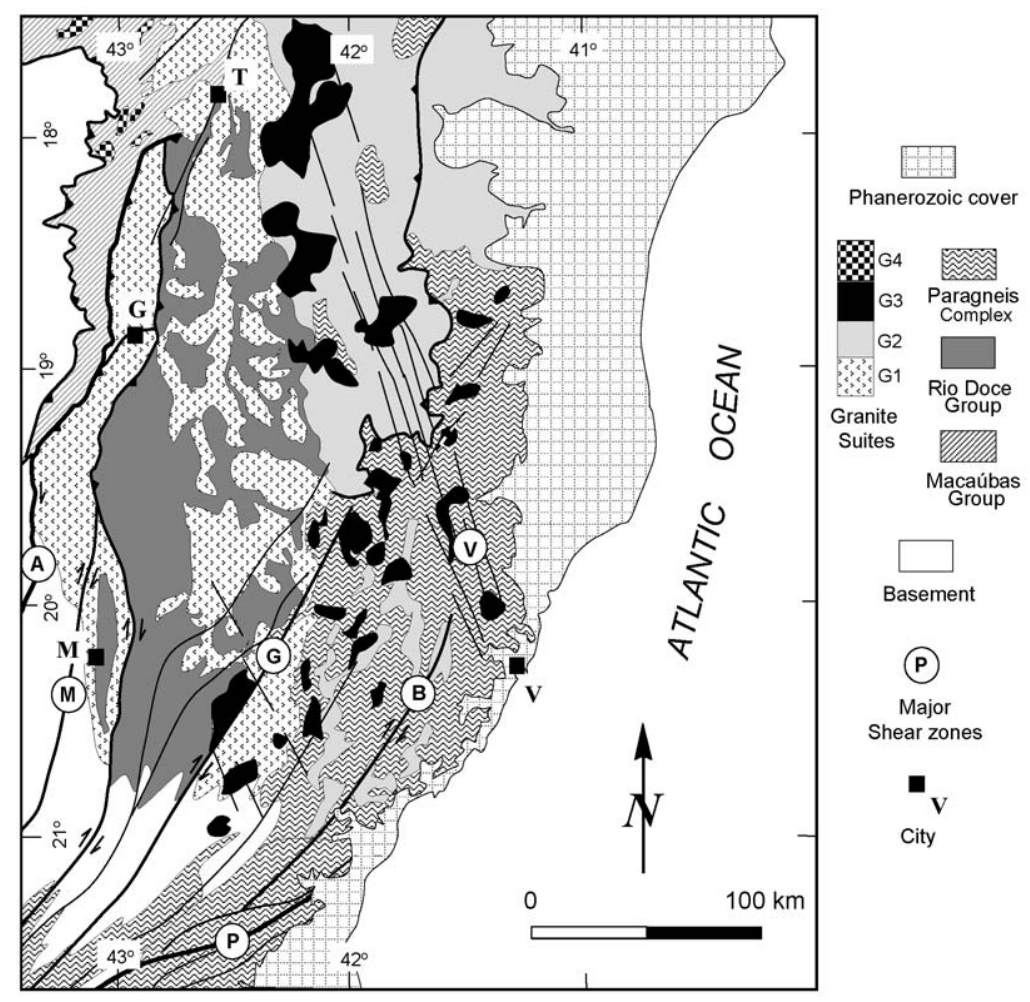

Fig. 10. Schematic structural map of the crystalline core of the AWC orogen. Major shear zones: $A=A b r e ~ C a m p o, M=M a n h u a c ̧ u, ~ G=G u a c ̧ u i ́$, $\mathrm{B}=$ Batatal, $\mathrm{P}=$ Além Paraíba. Cities: $\mathrm{V}=$ Vitória, $\mathrm{G}=$ Goverandor Valadares, $\mathrm{T}=$ Teófilo Otoni.

In the western portion of the northern sub-domain, west-verging thrust-sense shear zones placed precollisional granites of the G1 Suite over metabasalts that may be remnants of Neoproterozoic oceanic crust. To the north of $17^{\circ} \mathrm{S}$, structural grain in the northern subdomain follows the trace of the Rio Pardo salient (west of $42^{\circ} \mathrm{W}$ ) and the Itapebi shear zone (east of $42^{\circ} \mathrm{E}$ ). Between $19^{\circ} 30^{\prime} \mathrm{S}$ and $17^{\circ} \mathrm{S}$, foliation and shear zones developed in the paragneiss complex strike preferentially NNE and dip steeply to WNW. Kinematic indicators record a dominant dextral motion on the shear zones. A late-stage system of NNW-trending faults cuts across the earlier fabrics-this system is the Vitoria-Colatina shear zone.

The southern sub-domain contains a system of large-scale NNE-trending dextral strike-slip shear zones (Trompette et al., 1993). The most prominent of these are the Abre Campo, Manhuaçu, Guaçuí, and Batatal shear zones (Fig. 10; Cunningham et al., 1998). The Abre Campo shear zone can be traced for at least $300 \mathrm{~km}$, and marks a major structural and geophysical discontinuity in the Araçuaí orogen (Haralyi and Hasui, 1982). Specifically, it juxtaposes two categories of basement: the Archean Mantiqueira Complex (amphibolite facies) to the west, and the Paleoproterozoic the Juiz de Fora Complex (granulite facies) to the east. As such, this shear zone may represent a Paleoproterozoic suture (Cunningham et al., 1998; Fischel et al., 1998; Brueckner et al., 2000). In the region southwest of Governador Valadares, deep-ocean correlatives of the Macaúbas Group root in the Abre Campo shear zone, suggesting that the Abre Campo shear zone delineates a Brasiliano suture developed during closure of the oceanic portion of the Macaúbas basin. Support for this proposal comes from the observation that pre-collisonal (G1) arc-related plutons occur just to the east Abre Campo shear zone, at latitudes south of $18^{\circ} \mathrm{S}$ (Fig. 10). The dextral motion of the shear zones in the southern sub-domain was superimposed on an older set of tight to isoclinal west-verging folds (affecting gneissic foliation) and shallow dipping shear zones. Metamorphism associated with dextral shear occurred at lower amphibolite to greenschist grade, whereas the older set of structures formed under granulite-grade conditions (Cunningham et al., 1996, 1998). 

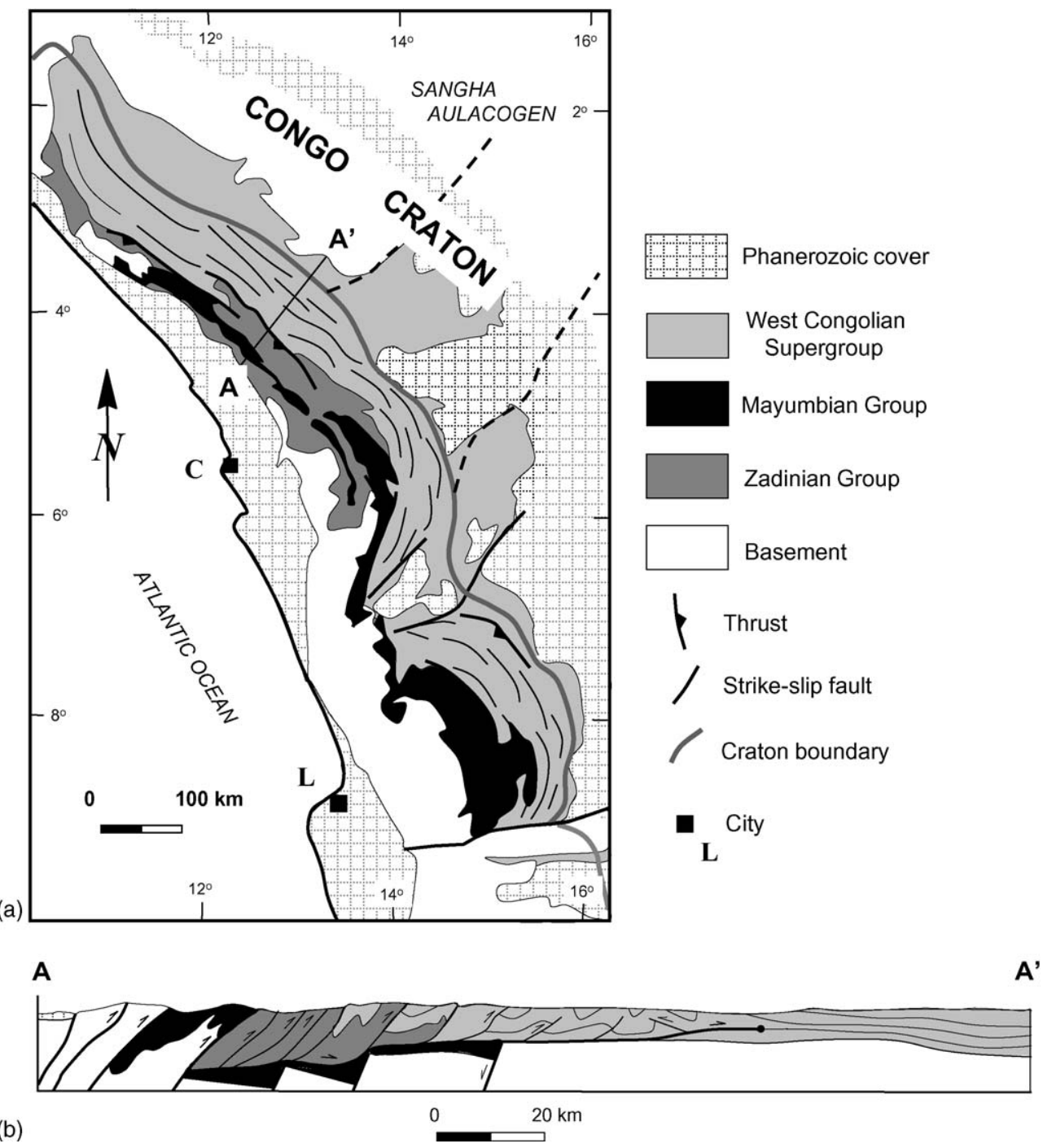

Fig. 11. (a) Simplified geologic map of the West Congo belt. Based on Maurin (1993) and Tack et al. (2001); (b) schematic cross-section of the central West Congo belt, based on Maurin (1993).

\subsection{The West Congo belt}

The NW-trending West Congo belt is an ENE-verging fold-thrust belt that lies on the west side of the Congo craton (Fig. 11a and b). In map view, trendlines of the belt are sinuous and define two salients and two recesses. The northern salient developed where the thrust belt propagates along the axis of the Sangha aulacogen (Alvarez and Maurin, 1991).

The hinterland (western) portion of the West Congo belt includes basement slices, thrust eastwards over Neoproterozoic high-grade metasediments of the Zadinian and Mayumbian Groups (Trompette, 1994; Tack et al., 2001). These high-grade metasediments were, in turn, thrust eastwards over Neoproterozoic greenschist- grade diamictites, which represent the basal portion of the West Congolian Group. Undeformed carbonate and clastic strata of the upper West Congolian Group lie beneath the easternmost thrusts of the belt (Fig. 11; Maurin, 1993; Tack et al., 2001). Rocks in thrust slices were intensely deformed to form tight asymmetric east-northeast-verging folds that contain a prominent axial-planar schistosity.

Overall, the structure of the West Congo belt suggests that it formed by inversion of the eastern side of the Macaúbas Basin. This portion of the basin differs from the part preserved in Brazil in that it contains significantly more Neoproterozoic bimodal volcanics, and was narrower. Such a contrast may indicate that the African side was the "upper plate" of the Macaúbas rift, whereas 
the Brazilian side was "lower plate" (terminology of Lister et al., 1986).

\section{Kinematic interpretation of the A-WC orogen}

\subsection{Previous models}

Models for evolution of the A-WC orogen have been postulated by Pedrosa-Soares et al. (1992), Trompette et al. (1992), and Maurin (1993) (Fig. 12). According to Pedrosa-Soares et al. (1992), the opening of the Macaúbas basin was accommodated at its north end by a transfer fault. During closure of the basin, renewed motion along this fault protected the cratonic bridge from deformation (Fig. 12a). Trompette et al. (1992) suggested that formation of the A-WC orogen was absorbed along a collisional belt along the Paramirim aulacogen (Fig. 12b). Maurin (1993) attributed the A-WC orogen to north-directed indentation, accommodated by strike-slip motion along the eastern and western margins of the orogen (Fig. 12c). Elements of these models probably do apply. However, none along can explain many geometric and kinematic aspects of the A-WC orogen.

\subsection{Nutcracker tectonics model}

Figs. 13 and 14 summarize kinematic data concerning the A-WC orogen that we presented in the previous sections. Several features of the orogen stand out:

- For most of its length, the A-WC orogen has the classic form of a bivergent orogen, with a high-grade internal zone bordered by external fold-thrust belts (the westverging Espinhaço fold-thrust belt on the west side, and the east-verging West Congo belt on the east side).

- In contrast to classic orogens, the A-WC orogen terminates against cratonic crust at its north end. This boundary is delineated by Rio Pardo salient and the northwest-trending, dextral Itapebi shear zone. Thus, the A-WC orogen does not follow the trace of the Paramirim aulacogen, which has been only partially inverted-in its northern half, faults retain a normal-

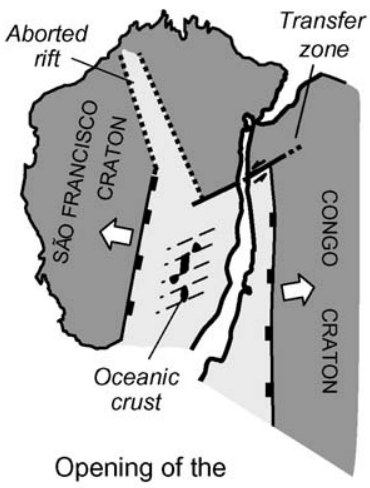

(a) Araçuai-West Congolian Rift

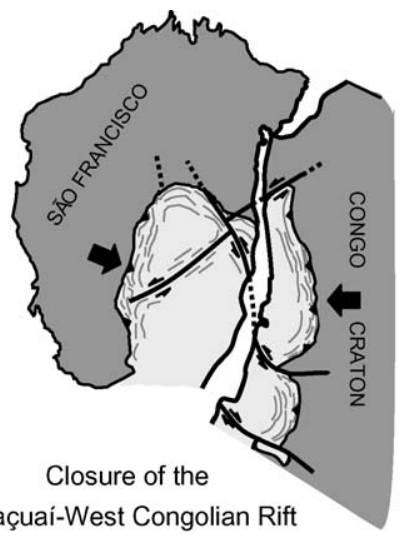

(b)

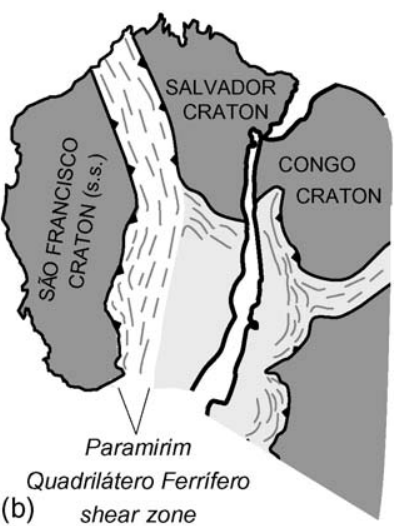

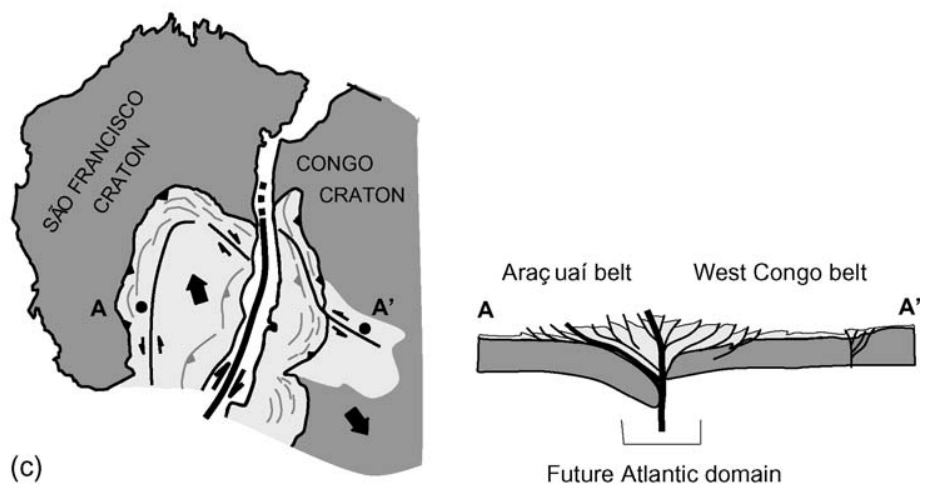

Fig. 12. Models postulated for the development of the A-WC orogen. (a) Pedrosa-Soares et al. (1992); (b) Trompette et al. (1992); (c) Maurin (1993). See text for explanation. 

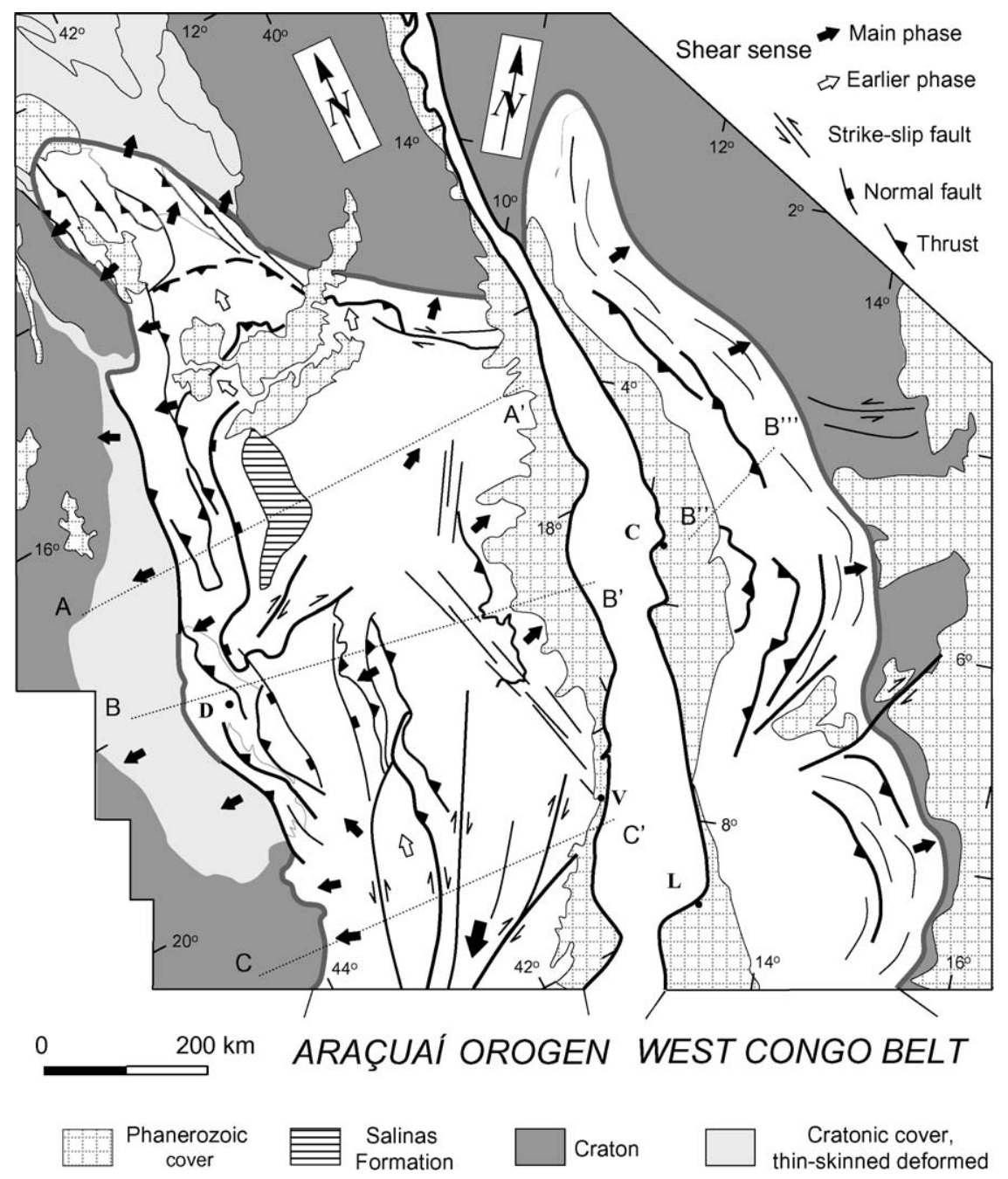

Fig. 13. Kinematic map of the A-WC orogen. Cities: V = Vitória, $\mathrm{D}=$ Diamantina, $\mathrm{L}=$ Luanda, $\mathrm{C}=\mathrm{Cabinda}$.

sense of slip. Similarly, there is no evidence for Neoproterozoic collision along the coasts of Brazil and Gabon.

- The oldest phase of Neoproterozoic deformation in the A-WC reflects top-to-the-north motion on shallowly dipping shear zones. This phase is preserved in the Rio Pardo Salient and in the crustal sliver between the Dom Silvério and Abre Campo shear zones.

- Neoproterzoic ocean-floor rock assemblage and subduction related granites do not occur north of $18^{\circ} \mathrm{S}$ latitude south of $18^{\circ} \mathrm{S}$ latitude, the ocean-floor rock assemblage roots in the Abre Campo shear zone, and G1 granites lie to east of it. The southern half of the precursor Macaúbas basin was, thus, floored by ocean. Its closure resulted in a suture, which is probably delineated by the Abre Campo shear zone.
- An array of NNE-trending dextral transpressional shear zones dominate the structural picture of the southern part of the orogen. The magnitude of strikeslip motion seems to increase progressively towards south.

- Development of the normal-sense Chapada Acauã shear zone overprinted thrust-sense deformation in the western A-WC orogen, and late- to post-tectonic granites intruded the interior of the orogen. Existence of these features suggests that a phase of extensional collapse affected the orogen.

The above observations, along with information available in the literature, lead us to postulate the following model for the evolution of the A-WC. We identify several kinematically distinct stages in this evolution, which we discuss in the next sections (Fig. 15). 
A

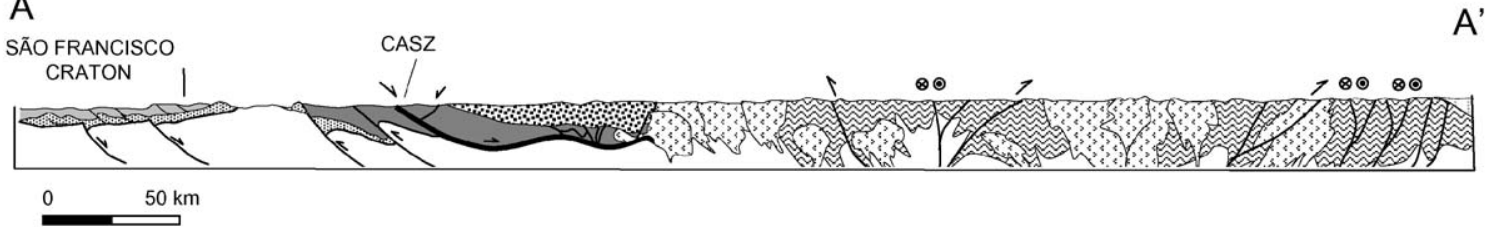

ARAÇUAI OROGEN

WEST CONGO BELT
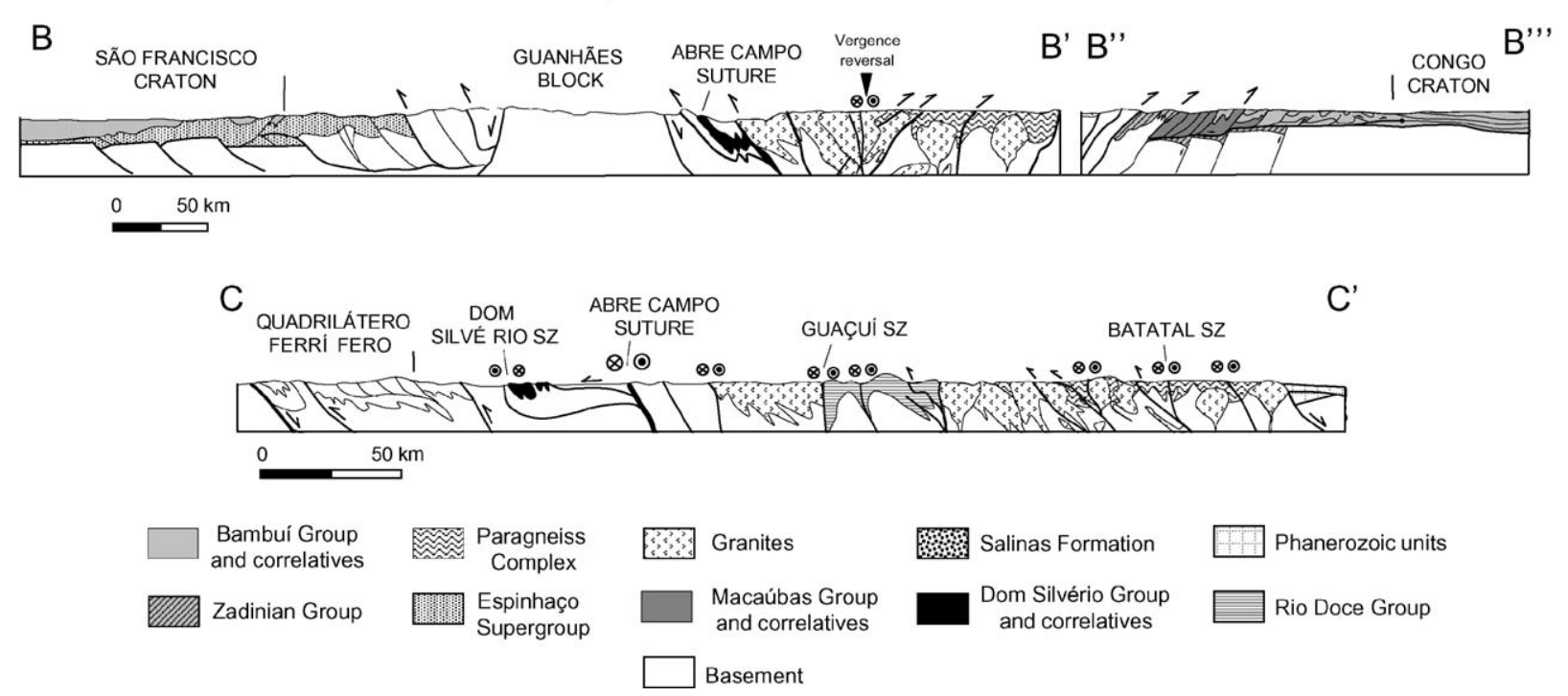

Fig. 14. Schematic cross-sections of the AWC orogen. For locations see Fig. 12.

\subsubsection{Stage 1: opening of the Macaúbas basin}

An extensional event around 900 Ma opened the Macaúbas basin and its intracratonic Sangha branch. This event reactivated the $1.75 \mathrm{Ga}$ Espinhaço rift system. The Macaúbas basin broadened progressively southward so by $800 \mathrm{Ma}$ (Fig. 15a and b) its southern half had become a narrow ocean.

\subsubsection{Stage 2: initial closure of the Macaúbas basin}

Arc-related granitic suites began to form around $625 \mathrm{Ma}$, so it appears that the Macaúbas basin began to close, and its oceanic portion began to be subducted, at this time. The downgoing slab at the south end of the Macaúbas basin dipped to the east, as indicated by the distribution of the pre-tectonic, subduction-related G1 suite, which forms a north-south-trending stripe in the orogens core south of $18^{\circ} \mathrm{S}$ (Fig. 10). Construction of this calc-alkaline magmatic arc lasted from about $625 \mathrm{Ma}$ until at least $585 \mathrm{Ma}$ (Pedrosa-Soares and WiedemannLeonardos, 2000).

Notably, the age of basin closure coincides approximately with collision of the Paranapanema block with the southwestern margin of the São Francisco craton (Seer et al., 2001; Valeriano et al., 2004) (Fig. 15b). We suggest, therefore, that collisions along the external margins of the São Francisco-Congo craton drove the closure of the Macaúbas basin. In this regard, the A-WC orogen can be viewed as a "forced orogen," in that its formation was driven by external collisions rather than by slab-pull force alone. This proposal can explain why closure continued sufficiently to cause substantial crustal thickening and continued magmatism after the ocean crust of the southern Macaúbas basin had been entirely subducted.

In our model, the southern arm of the São Francisco craton rotated counterclockwise, relative to the Congo craton, around an axis located at the northwest end of the Paramirim aulacogen. We place the axis at the point where inversion in the aulacogen dies out. This rotation initially resulted in oblique convergence within the orogen (Fig. 15b).

At an early stage of closure, northward (i.e., alongstrike) transport occurred in the interior of the orogen. The context of this phase of remains unclear; it could reflect accommodation of room problems developed in response to a promontory protruding from the southern end of the São Francisco craton. 


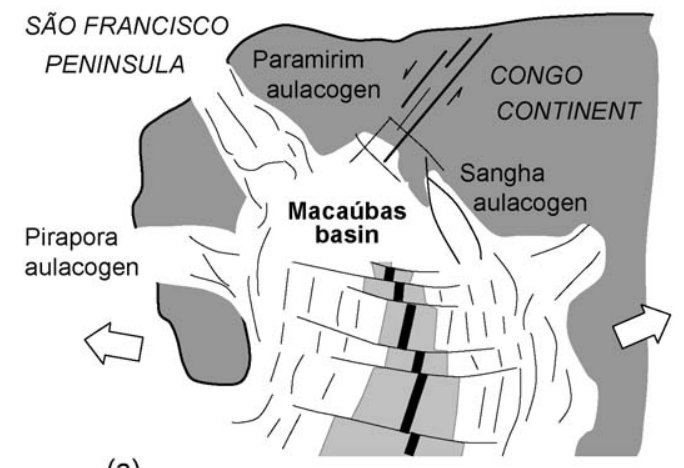

(a)

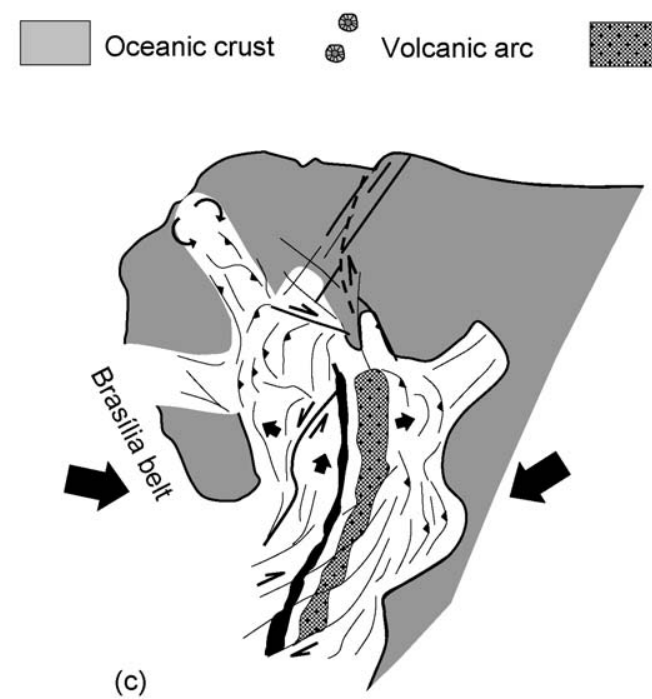

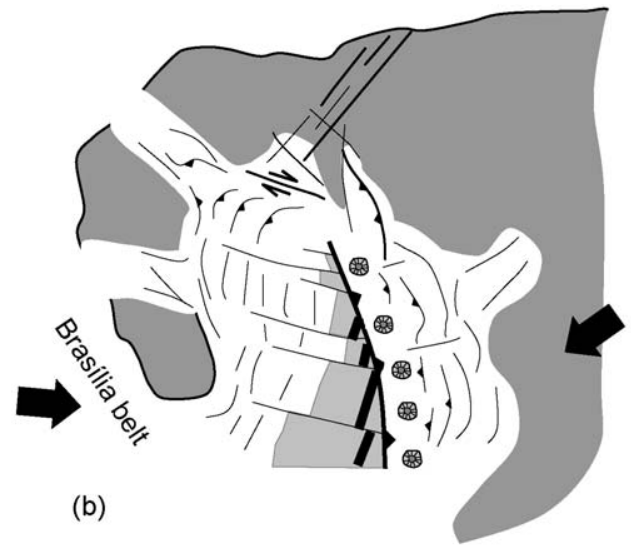

Granite plutons Salinas Formation

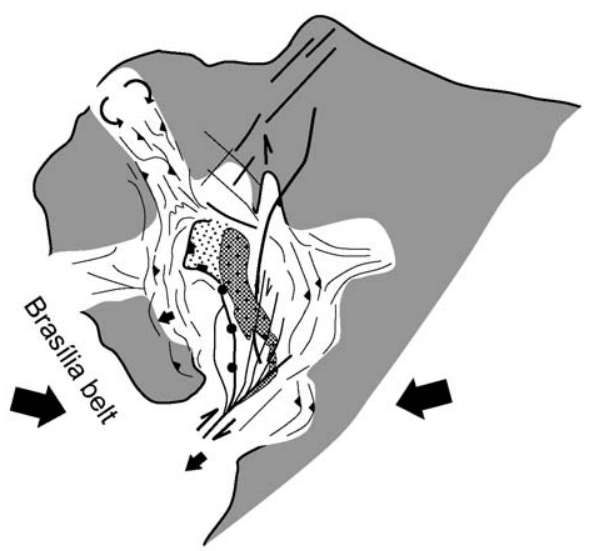

(d)

Fig. 15. Cartoon illustrating the nutcracker tectonics model for the evolution of the A-WC orogen. (a) The Macaúbas basin, ancestor of the A-WC orogen, at ca. $800 \mathrm{Ma}$; (b) Initial closure of the Macaúbas basin, at ca. $600 \mathrm{Ma}$, as a consequence of the São Francisco-Congo, Paranapanema, and Kalahari interaction; (c) full development of the orogen at ca. $570 \mathrm{Ma}$; (d) southward escape of the southern portion of the A-WC orogen and its extensional collapse at around $500 \mathrm{Ma}$.

\subsubsection{Stage 3: full closure of the Macaúbas}

basin-the collisional stage

As the nutcracker continued to close, the passive margins on either side of the now-closed ocean basin underwent inversion. As a result, foreland-verging external fold-thrust belts evolved (verging east on the African side and west on the Brazil side). With continued shortening, the thrust front propagated toward the foreland, and transported basin strata up and over the edges of the cratons (Fig. 15c). At an early stage of closure, thrust sheets propagated northwards along the axis of the Paramirim aulacogen-with continued closure, east-west shortening folded these thrust sheets. Peak metamorphism, and intrusion of the G2 syn-tectonic granite suite, occurred during this stage. Dates of these rocks fall between 585 and $560 \mathrm{Ma}$ (Pedrosa-Soares and Wiedemann-Leonardos, 2000; Pedrosa-Soares et al., 2001; Silva et al., 2005). There may have been sinistral strike-slip shear along the boundary between the São Francisco craton and the Congo craton, but the region is now submerged beneath the Atlantic, so this proposal cannot be confirmed. There is no evidence for thrusting along this boundary.

\subsubsection{Stage 4: southward escape of the southern A-WC orogen}

At a late stage (560-535 Ma) during the collision, as the nutcracker's arms continued to close, a room problem developed in the southern portion of the orogen (Fig. 15d). At this stage Kalahri collided with Congo, and other components of the southern branch of the Brasiliano/Pan-African system initiated (Prave, 1996; 
Kisters et al., 2004; Silva et al., 2005). We suggest that, to accommodate this room problem, the southern portion of the orogen underwent lateral escape to the southwest. The escape was accommodated by shear on the system of northeast-trending dextral strike-slip faults now exposed in the region. As structures bent around the stronger southern end of the São Francisco craton, oroclinal rotation of the southern portion of the orogen may have taken place (Trompette et al., 1993).

\subsubsection{Stage 5: orogenic collapse}

During the final phase of closure, the extremely thickened northern half of the internal zone underwent extensional collapse. Shear on regional normalsense detachments and normal faults may have played a role in exhuming especially the central portion of the Guanhães basement block-in this regard, its central sector behaved like a metamorphic core complex.

We suggest that collapse triggered igneous activity, due to decompression and partial melting of mid- and lower crustal levels, producing the G4 through G5 granite suites (520-490 Ma). The great volume of magma generated at this time remains puzzling. We speculate that it may be related to the delamination and sinking of the lithospheric mantle, or to residual rise of asthenosphere associated with the subduction of the ridge of the narrow Macaúbas ocean.

\section{Conclusions}

The origin of the Araçuaí-West Congo (A-WC) orogen has been a long-standing enigma in tectonic models of the assembly of West Gondwana. It appears to be a "confined orogen", in the sense that it was bordered on three sides by cratonic crust at the time it formed. In this context, it is hard to see how there could be sufficient closure to cause the extensive deformation, metamorphism, and igneous activity now found in the belt. To explain this enigma, we suggest that the A-WC orogen represents closure of a Red Sea type ocean (floored by ocean crust to the south, and stretched continental crust to the north) as the São Francisco Congo craton rotated toward the Congo craton, like the pincers of a nutcracker, squashing the Macaúbas basin that lay in-between. The driving force for this closure came from the impact of the Paranapanema, Amazonia and Kalahari against the external margins of the São Francisco Congo cratons-in effect, the Macaúbas basin was forced closed.

Closure involved subduction of oceanic floor in the southern part of the A-WC orogen, and inversion of a continental rift in the northern part. Eventually, closure produced extreme crustal thickening, followed by extensional collapse, which produced voluminous postcollisional granitic melts. During or after extensional collapse, the southern portion of the orogen underwent lateral escape to the south along an array of northeasttrending dextral-transpressive faults. The A-WC orogen may serve as an example for how Precambrian partially ensialic orogens develop.

\section{Acknowledgements}

This work was supported by $\mathrm{CNPq}$ (Conselho Nacional de Desenvolvimento Científico e Tecnológico, Brazil) grant 572953/97-6, FAPEMIG grant CRA394/2002 and NSF (National Science Foundation, USA) grant EAR 99-02730. The authors are grateful to two anonymous reviewers, whose criticism led to significant improvement of the manuscript.

\section{References}

Alkmim, F.F., Marshak, S., 1998. Transamazonian orogeny in the southern São Francisco craton region, Minas Gerais Brazil: evidence for Paleoproterozoic collision and collapse in the Quadrilátero Ferrífero. Precambrian Res. 90, 29-58.

Alkmim, F.F., Marshak, S., Fonseca, M.A., 2001. Assembling West Gondwana in the Neoproterozoic: clues form the São Francisco craton region, Brazil. Geology 29, 319-322.

Almeida, F.F.M., Brito Neves, B.B., Carneiro, C.D.R., 2000. Origin and evolution of the South American Platform. Earth Sci. Rev. 50, $77-111$

Almeida, F.F.M., Hasui, Y., Brito Neves, B.B., Fuck, R.A., 1981. Brazilian structural provinces: an introduction. Earth Sci. Rev. 17, $1-29$.

Alvarez, P., 1995. Evidence for a Neoproterozoic carbonate ramp on the northern edge of the Central African craton: relations with late proterozoic intracratonic troughs. Geologische Rundschau 84, 636-648.

Alvarez, P., Maurin, J.-C., 1991. Evolution sédimentaire et tectonique du basin protérozoïque supérieur de Comba (Congo): stratigraphie séquentielle du Supergroupe Ouest-Congolien et modélle d'amortissement sur déchrochements dans le contexte de tectogénèse panafricaine. Precambrian Res. 50, 137171.

Babinski, M., Kaufman, A.J., 2003. First direct dating of a Neoproterozoic post-glacial cap carbonate. In: South American Symposium on Isotope Geology, vol. 4, Salvador, BA, Brazil, pp. 321-323 (short papers).

Barbosa, J.S.F., Sabaté, P., 2004. Archean and Paleoproterozoic crust of the São Francisco craton, Bahia, Brazil: geodynamic features. Precambrian Res. 133, 1-27.

Boudzoumou, F., Trompette, R., 1988. La chaîne panafricaine ouest-congolienne au Congo (Afrique Equatoriale): un socle polycyclique charrié sur un domaine subautochtone formé par l'aulacogene du Mayombe et le bassin de l'Ouest-Congo. Bulletin de la Société Géologique de France 6, 889-896.

Brito Neves, B.B., Campos Neto, M.C., Fuck, R., 1999. From Rodinia to Western Gondwana: an approach to the Brasiliano/Pan-African cycle and orogenic collage. Episodes 22, 155-199. 
Brito Neves, B.B., Sá, J.M., Nilson, A.A., Botelho, N.F., 1996. A tafrogênese estateriana nos blocos paleoproterozóicos da América do Sul e processos subseqüentes. Geonomos 3, 1-21.

Brueckner, H.K., Cunningham, D., Alkmim, F.F., Marshak, S., 2000. Tectonic implications of Precambrian Sm-Nd dates from the southern São Francisco craton and adjacent Araçuaí and Ribeira belts, Brazil. Precambrian Res. 99, 255-269.

Cahen, L., Snelling, N.J., Delhal, J., Vail, J.R., 1984. The Geochronology of Africa. Clarendon Press, Oxford, 512 pp.

Chemale Jr., F., Quade, H., Van Schmus, W.R., 1977. Petrography, geochemistry and geochronology of the Borrachudos and Santa Bárbara metagranites, Quadrilátero Ferrífero, Brazil. Zentralblatt für Geologie und Paläontologie, 739-750.

Chemale Jr., F., Rosière, C.A., Endo, I., 1994. The tectonic evolution of the Quadrilátero Ferrífero, Minas Gerais, Brazil. Precambrian Res. 65, 25-54.

Corrêa-Gomes, L.C., Oliveira, E.P., 2000. Radiating 1.0 Ga. Mafic dyke swarms of eastern Brazil and Western Africa: evidence for post-assembling extension in the Rodinia supercontinent? Gondwana Res. 3, 325-332.

Cruz, S.C.P., Alkmim, F.F., 2006. The tectonic interaction between the Paramirim Aulacogen and the Araçuaí belt, São Francisco Craton Region, Eastern Brazil. Anais da Academia Brasileira de Ciências 78 (1), 151-173.

Cunningham, W.D., Marshak, S., Alkmim, F.F., 1996. Structural style of basin inversion at mid-crustal levels: two transects in the internal zone of the Brasiliano Araçuaí Belt, Minas Gerais, Brazil. Precambrian Res. 77, 1-15.

Cunningham, D., Alkmim, F.F., Marshak, S., 1998. A structural transect across the coastal mobile belt in the Brazilian Highlands (latitude $20^{\circ} \mathrm{S}$ ): the roots of a Precambrian transpressional orogen. Precambrian Res. 92, 251-275.

D’Agrella Filho, M.S., Pacca, I.I.G., Teixeira, W., Onstott, T.C., Renne, P.R., 1990. Paleomagnetic evidence for the evolution of Meso-to Neo-Proterozoic glaciogenic rocks in CentralEastern Brazil. Palaeogeogr. Palaeoclimatol. Palaeoecol. 80, 255 265.

D’Agrella Filho, M.S., Pacca, I.I.G., Trindade, R.I.F., Teixeira, W., Raposo, M.I.B., Onstott, T.C., 2004. Paleomagnetism and ${ }^{40} \mathrm{Ar}^{39} \mathrm{Ar}$ ages of mafic dykes from Salvador (Brazil): new constraints on the São Francisco Craton APW path between 1080 and 1010 Ma. Precambrian Res. 132, 55-77.

Danderfer, A., Dardenne, M.A., 2002. Tectonoestratigrafia da Bacia Espinhaço na porção centro-norte do Cráton do São Francisco: Registro de uma evolução poli-histórica descontínua. Revista Brasileira de Geociências 32, 449-460.

Daziel, I.W.D., 1997. Neoproterozoic-Paleozoic geography and tectonics: review, hypothesis, environmental speculation. Geol. Soc. Am. Bull. 109, 16-42.

De Wit, M., Jeffery, M., Bergh, H., Nicolaysen, L., 1988. Geologic Map of Sectors of Gondwana. AAPG and University of Witwatersrand, Tulsa.

Dussin, T.M., 2000. A tectônica extensional paleoproterozóica na borda sudeste do Cráton do São Francisco (SE, Brasil): Geoquímica e petrologia das meta-ígneas. Geonomos 8, 63-68.

Dussin, I.A., Dussin, T.M., 1995. Supergrupo Espinhaço: Modelo de evolução geodinâmica. Geonomos 3, 19-26.

Feybesse, J.L., Johan, V., Triboulet, C., Guerrot, C., Mayaga-Mikolo, F., Bouchot, V., Eko N'dong, J., 1998. The West central African belt: a model of 2.5-2.0 Ga accretion and two-phase orogenic evolution. Precambrian Res. 87, 161-216.
Fischel, D.P., Pimentel, M.M., Fuck, R.A., Costa, A.G., Rosière, C.A., 1998. Geology and Sm-Nd isotopic data for the Mantiqueira and Juiz de Fora complexes (Coastal Mobile belt) in the Abre Campo region, Minas Gerais, Brazil. In: International Conference on Precambrian and Craton Tectonics, Univ. Federal de Ouro Preto, Ouro Preto, Brazil, pp. 21-23 (abstracts).

Gonçalves, J.C.V., Melo, R.C., 2004. Extremo Sul da Bahia: Geologia e Recursos Minerais Serviço Geológico do Brasil CPRM, Série Arquivos Abertos 19, 54 pp.

Haralyi, N.L.E., Hasui, Y., 1982. The gravimetric information and Archean-Proterozoic structural framework of eastern Brazil. Revista Brasileira de Geociências 112, 160-166.

Heilbron, M., Machado, N., 2003. Timing of terrane accretion in the Neoproterozoic-Eopaleozoic Ribeira orogen (SE Brazil). Precambrian Res. 125, 87-112.

Heilbron, M., Mohriak, W.U., Valeriano, C.M., Milani, E.J., Almeida, J., Tupinambá, M., 2000. From collision to extension: the roots of the southeastern continental margin of Brazil. In: Atlantic Rifts, Continental Margins, Geophysical Monograph 115, American Geophysical Union, pp. 1-32.

Heilbron, M., Pedrosa-Soares, A.C., Neto, M., da Silva, L., Trouw, R., Janasi, V. 2004. Brasiliano Orogens in Southeast and South Brazil. In: Wienberg, R., Trouw, R., and Hackspacher, P. (Eds.), The 750-550 Ma Brasiliano Event of South America. J. Virtual Explorer. Electronic Edition 17, Paper 4.

Kaufmann A.J., Varni, M.A., Misi, A., Brito-Neves, B.B., 2001. Anomalous $\delta^{34} \mathrm{~S}$ signatures in trace sulfate from a potential cap carbonate in the Neoproterozoic Bambuí Group, Brazil. In: Misi, A., Teixeira, J.B. (Orgs), Contributions Presented at the First IGCP 450 Field Workshop, Belo Horizonte and Paracatu, pp. 62-65.

Kisters, F.M., Jordaan, L.S., Neumaier, K., 2004. Thrust-related dome structures in the Karibib district and the origin of orthogonal fabric domains in the south Central Zone of the Pan-African Damara belt, Namibia. Precambrian Res. 133, 283-303.

Ledru, P.J., Johan, V., Milési, J.P., Tegycy, M., 1994. Markers of the last stage of the Paleoproterozoic collision: evidence for a $2 \mathrm{Ga}$ continent involving circum-South Atlantic provinces. Precambrian Res. 69, 169-191.

Lerouge, C., Cocherie, A., Toteu, S.F., Penaye, J., Milési, J.P., Tchameni, R., Nsifa, E.N.C., Fanning, M., Deloule, E., 2006. Shrimp U-Pb zircon age evidence for Paleoproterozoic sedimentation and $2.05 \mathrm{Ga}$ syntectonic plutonism in the Nyong Group, South-Western Cameroon: consequences for the Eburnean-Transamazonian belt of NE Brazil and Central Africa. J. Afr. Earth Sci. 44, 127-413.

Lima, S.A.A., Martins-Neto, M.A., Pedrosa-Soares, A.C., Cordani, U.G., Nutman, A., 2002. A Formação Salinas na área-tipo, NE de Minas Gerais: Uma proposta de revisão da estratigrafia da Faixa Araçuaí com base em evidências sedimentares, metamórficas e idades U-Pb SHRIMP. Revista Brasileira de Geociências 32, 491-500.

Lister, G.S., Ethridge, M.A., Symonds, P.A., 1986. Detachment faulting and the evolution of continental margins. Geology 14, 246250 .

Marshak, S., Alkmim, F.F., 1989. Proterozoic contraction/extension tectonics of the southern São Francisco region, Minas Gerais, Brazil. Tectonics 8, 555-571.

Marshak, S., Alkmim, F.F., Whittington, A., Pedrosa-Soares, A.C., 2006. Extensional collapse in the Neoproterozoic Araçuaí orogen, eastern Brazil: a setting for reactivation of asymmetric crenulation cleavage. J. Struct. Geol. 28, 129-147. 
Martins, V.T.S., Teixeira, W., Noce, C.M., Pedrosa-Soares, A.C., 2004. $\mathrm{Sm}$ and Nd characteristics of Brasiliano/Pan-African granitoid plutons of the Araçuaí Orogen Southeastern Brazil: Tectonic implications. Gondwana Res. 7 (1), 75-89.

Martins-Neto, M.A., 2000. Tectonics and sedimentation in a paleomesoproterozoic rift-sag basin (Espinhaço basin, southeastern Brazil). Precambrian Res. 103, 147-173.

Martins-Neto, M.A., Hercos, C.M., 2000. Sedimentation and Tectonic Setting of Early Neoproterozoic Glacial Deposits in Southeastern Brazil, vol. 33. Special Publication International Association of Sedimentologists, pp. 383-403.

Martins-Neto, M.A., Pedrosa-Soares, A.C., Lima, S.A.A., 2001. Tectono-sedimentary evolution of sedimentary basins from Late Paleoproterozoic to Late Neoproterozoic in the São Francisco craton and Araçuaí fold belt, eastern Brazil. Sediment. Geol. 141/142, 343-370.

Matos, R.M.D., 1999. History of the northeast Brazilian rift system: kinematic implications for the break-up between Brazil and Africa. In: Cameron, N.R., Bate, R.H., Clure, V.S. (Eds.), The Oil and Gas Habitats of South Atlantic. Geological Society of London Special Publication 153, pp. 55-73.

Maurin, J.-C., 1993. La chaîne panafricaine ouest-congolienne: corrélation avec le domain est-brésilien et hypothese gódynamique. Bulletin de la Société Géologique de France 164, 51-60.

Misi, A., Iyer, S.S., Coelho, C.E.S., Tassinari, C.C.G., Francarocha, W.J., Cunha, I.A., Gomes, A.S., Oliveira, T.F., Teixeira, J.B.G., Monaco, V.C., 2005. Sediment-hosted lead-zinc deposits of the Neoproterozoic Bambuí group and correlative sequences, São Francisco Craton, Brazil: a review and a possible metallogenic evolution model. Ore Geol. Rev. 26, 263-304.

Noce, C.M., Macambira, M.B., Pedrosa-Soares, A.C., 2000. Chronology of Neoproterozoic-Cambrian granitic magmatism in the Araçuaí Belt, Eastern Brazil, based on single zircon evaporation dating. Revista Brasileira de Geociências 30 (1), 25-29.

Noce, C.M., Pedrosa-Soares, A.C., Piuzana, D., Armstrong, R., Laux, J.H., Campos, C., Medeiros, S.R., 2004. Ages of sedimentation of the kinzigitic complex and of a late orogenic thermal episode in the Araçuaí orogen, Northern Espírito Santo state, Brazil: zircon and monazite U-Pb SHRIMP and ID-TIMS data. Revista Brasileira de Geociências 349 (4), 587-592.

Pedrosa-Soares, A.C., Noce, C.M., Vidal, P., Monteiro, R.L.B.P., Leonardos, O.H., 1992. Toward a new tectonic model for the Late Proterzoic Araçuaí (SE Brazil)-West Congolian (SW Africa) Belt. J. South Am. Earth Sci. 6, 33-47.

Pedrosa-Soares, A.C., Vidal, P., Leonardos, O.H., Brito-Neves, B.B., 1998. Neoproterozoic oceanic remnants in eastern Brazil: further evidence and refutation of an exclusively ensialic evolution for the Araçuaí-West Congo Orogen. Geology 26, 519-522.

Pedrosa-Soares, A.C., Wiedemann-Leonardos, C.M., 2000. Evolution of the Araçuaí belt and its connection to the Ribeira Belt, Eastern Brazil. In: Cordani, U.G., Milani, E.J., Thomaz Filho, A., Campos, D.A. (Eds.), Tectonic Evolution of South America. International Geological Congress, Rio de Jameiro, pp. 265285.

Pedrosa-Soares, A.C., Cordani, U.G., Nutman, A., 2000. Constraining the age of Neoproterozoic glaciation in eastern Brazil: first $\mathrm{U}-\mathrm{Pb}$ (SHRIMP) data from detrital zircons. Revista Brasileira de Geociências 30 (1), 58-61.

Pedrosa-Soares, A.C., Noce, C.M., Wiedemann, C.M., Pinto, C.P., 2001. The Araçuaí-West Congo orogen in Brazil: an overview of a confined orogen formed during Gondwanland assembly. Precambrian Res. 110, 307-323.
Peres, G.G., Alkmim, F.F., Jordt-Evangelista, H., 2004. The southern Araçuaí belt and the Dom Silvério Group: geologic architecture and tectonic significance. Anais da Academia Brasileira de Ciências 76, 771-790.

Porada, H., 1989. Pan-African rifting and orogenesis in southern to equatorial Africa and Eastern Brazil. Precambrian Res. 44, 103-136.

Prave, A.R., 1996. Tale of three cratons: tectonostratigraphic anatomy of the Damara Orogen in northwestern Namibia and the assembly of Gondwana. Geology 24, 115-118.

Renne, P.R., Onstott, T.C., D'agrella Filho, M.S., Pacca, I.I.G., Teixeira, W., 1990. ${ }^{40} \mathrm{Ar} /{ }^{39} \mathrm{Ar}$ dating of $10-1.1 \mathrm{Ga}$ magnetizations from the São Francisco and Kalahari Cratons: tectonic implications for Pan-African and Brasiliano mobile belts. Earth Planet. Sci. Lett. 101, 349-366.

Ribeiro-Althoff, A.M., Cheilletz, A., Guiliani, G., Féraud, G., Barbosa-Camacho, G., Zimmermann, J.L., 1997. ${ }^{40} \mathrm{Ar} /{ }^{39} \mathrm{Ar}$ and $\mathrm{K}-\mathrm{Ar}$ geochronological evidence for two periods $(\sim 2 \mathrm{Ga}$ and 650-500 Ma) of emerald formation in Brazil. Int. Geol. Rev. 39, 924-937.

Schobbenhaus, C., 1996. As tafrogêneses superpostas Espinhaço e Santo Onofre, Estado da Bahia: Revisão e novas propostas. Revista Brasileira de Geociências 26 (4), 265-276.

Seer, H.J., Brod, J.A., Fuck, R.A., Pimentel, M.M., Boaventura, G.R., Dardenne, M.A., 2001. Grupo Araxá em sua área tipo: Um fragmento de crosta oceânica neoproterozóica na Faixa de Dobramento Brasília. Revista Brasileira de Geociências 31, 396924.

Silva, L.C., Amstrong, R., Delgado, I.M., Pimentel, M., Arcanjo, J.B., Melo, R.C., Teixeira, L.R., Jost, H., Cardoso Filho, J.M., Pereira, L.H.M., 2002. Reavaliação da evolução geológica em terrenos précambrianos brasileiros com base em novos dados U-Pb SHRIMP. Parte I. Limite centro-oriental do Cráton do São Francisco na Bahia. Revista Brasileira de Geociências 32 (4), 161-172.

Silva, L.C., McNaughton, N.J., Armstrong, R., Hartmann, L.A., Fletcher, I.R., 2005. The Neoproterozoic Mantiqueira Province and its African connections: a zircon-based $\mathrm{U}-\mathrm{Pb}$ geochronologic subdivision for the Brasiliano/Pan-African system of orogens. Precambrian Res. 136, 203-240.

Tack, L., Wingate, M.T.D., Liégeois, J.-P., Fernandez-Alonso, M., Deblond, A., 2001. Early Neoproterozoic magmatism (1000-910 Ma) of the Zadinian and Mayumbian Groups (BasCongo): onset of Rodinian rifting at the western edge of the Congo craton. Precambrian Res. 110, 277-306.

Toteu, S.F., Van Schmus, W.R., Penaye, J., Nyobé, J.B., 1994. U-Pb and $\mathrm{Sm}-\mathrm{Nd}$ evidence for Eburnian and Pan-African high-grade metamorphism in cratonic rocks of southern Cameroon. Precambrian Res. 67, 321-347.

Trompette, R., 1994. Geology of Western Gondwana (2000-500 Ma). In: Pan-African/Brasiliano aggregation of South America and Africa. A.A. Balkema, Rotterdam, 350 pp.

Trompette, R., 1997. Neoproterozoic ( $600 \mathrm{Ma})$ aggregation of Western Gondwana: a tentative scenario. Precambrian Res. 82, 101112.

Trompette, R., Uhlein, A., Egydio-Silva, M.E., Karmann, I., 1992. The Brasiliano São Francisco craton revisited (central Brazil). J. South Am. Earth Sci. 6, 49-57.

Trompette, R., Egydio-Silva, M., Tommasi, A., Vauchez, A., Uhlein, A., 1993. Amalgamação do Gondwana Ocidental no PanafricanoBrasiliano e o papel da geometria do Cráton do São Francisco na arquitetura da Faixa Ribeira. Revista Brasileira de Geociências 23, 187-193. 
Uhlein, A., Trompette, R., Silva, M.E., 1986. A estruturação tectônica do Supergrupo Espinhaço na região de Diamantina, MG. Revista Brasileira de Geociências 16, 212-216.

Uhlein, A., Trompette, R.R., Alvarenga, C.J.S., 1999. Neoproterozoic glacial and gravitational sedimentation on a continental rifted margin: the Jequitaí-Macaúbas sequence (Minas Gerais, Brazil). J. South Am. Earth Sci. 12, 435-451.

Uhlein, A., Trompette, R.R., Egydio-Silva, M., 1998. Proterozoic rifting and closure, SE border of the São Francisco Craton, Brazil. J. South Am. Earth Sci. 11, 191-203.
Valeriano, C.M., Machado, N., Simonetti, A., Valladares, C.S., Seer, H.J., Simões, L.S.A., 2004. U-Pb geochronology of the southern Brasilia belt (SE-Brazil): sedimentary provenance. Neoproterozoic orogeny and assembly of West-Gondwana. Precambrian Res. 130 $(1 / 4), 27-55$.

Wiedemann, C.M., Campos, C.M., Medeiros, S.R., Mendes, J.C., Ludka, I.P., Moura, J.C., 2002. Architecture of Late Orogenic Plutons in the Aracuaí-Ribeira Folded Belt, Southeast Brazil. Gondwana Res. 19, 381-399. 